\title{
Growth of bacterioplankton and consumption of dissolved organic carbon in the Sargasso Sea
}

\author{
Craig A. Carlson ${ }^{1, *}$, Hugh W. Ducklow ${ }^{2}$ \\ ${ }^{1}$ Horn Point Environmental Laboratory, University of Maryland, PO Box 775, Cambridge, Maryland 21613, USA \\ ${ }^{2}$ The College of William and Mary, Virginia Institute of Marine Sciences, PO Box 1346, Gloucester Point, Virginia 23062-1346, USA
}

\begin{abstract}
Lability of the bulk dissolved organic carbon (DOC) pool and the amount available to bacterioplankton on short time scales (hours to days) were examined in oligotrophic Sargasso Sea water (near Bermuda). We examined bacterial growth and DOC utilization using seawater culture methodology in combination with measurements of bacterial abundance, cell volume, and DOC. Bulk DOC concentrations were determined by high temperature combustion ( $\mathrm{HTC}$ ) analysis, which proved to be a sensitive method for detecting small changes in natural concentration of DOC. Measurable bacterial growth and DOC utilization only occurred in unamended cultures when initial DOC concentrations were greater than observed in the mixed layer at the Bermuda Atlantic Time Series station. In unamended cultures exhibiting growth, approximately 6 to $7 \%$ of the bulk pool was available and considered a labile component. This material was utilized with an average bacterial growth efficiency (BGE) of $14 \pm 6 \%$. Nutrient enrichment experiments were also conducted with $\mathrm{NH}_{4}, \mathrm{PO}_{4}$, glucose, dissolved free amino acid (DFAA) and algal lysate additions. In all experiments bacterial growth rates, bacterial carbon production, and BGE increased with the addition of organic carbon supplements. There were no enhancements of bacterial production or DOC utilization above the control when inorganic nutrients were added, indicating that at the time these experiments were conducted bacterial growth was limited by available carbon.
\end{abstract}

KEY WORDS: Dissolved organic carbon - Bacterioplankton · Growth efficiency

\section{INTRODUCTION}

Dissolved organic carbon (DOC) represents the largest pool of reduced carbon in the ocean. Recent reports have demonstrated temporal and spatial variability of this bulk pool in the surface ocean (CopinMontégut \& Avril 1993, Carlson et al. 1994, Peltzer \& Hayward in press), indicating that significant portions of this bulk pool are dynamic and consist of material of varying lability. While a large portion of the bulk DOC pool in the surface ocean consists of refractory material which turns over on the time scale of millennia, the remainder of the surface DOC pool consists of semilabile material which turns over on the scale of months to years and labile material which turns over on the

- Present address: Bermuda Biological Station for Research Inc., Ferry Reach, St. Georges GE01, Bermuda

E-mail: ccarlson@bbsr.edu scale of hours to days. Separating the refractory pool from the semi-labile and labile pool can be done by observing surface accumulation of DOC above background deep water $(>1000 \mathrm{~m}$ ) and assuming equal distribution of refractory material throughout the water column (see Carlson \& Ducklow 1995). But separating the semi-labile and labile pools is more difficult because only about $30 \%$ of the bulk DOC pool can be identified chemically (Williams \& Druffel 1988); thus, we must depend on biological assays to further partition these pools (Servais et al. 1989).

Bacterioplankton mediate the flux of dissolved organic matter (DOM); thus, factors which regulate bacterial growth can ultimately affect the magnitude of semi-labile and labile carbon accumulation. Several studies have suggested that bacterial growth may be limited by the availability of inorganic nutrients such as N and P (Toolan et al. 1991, Kroer 1993, Zweifel et al. 1993, Cotner et al. 1994), indicating that there is 
a surplus of available labile $\mathrm{C}$ but that its uptake is limited by the supply of inorganic nutrients. Other studies suggest that oceanic bacterioplankton are indeed limited by the supply of labile carbon (Kirchman et al. 1990, Kirchman 1994). To better understand the dynamics of the bulk DOC pool of the oligotrophic ocean, we must first understand how much of the bulk pool is available to bacteria and at what efficiency this material is used. Second, we must determine if the availability of DOC and the efficiency of its use are affected by the presence of inorganic nutrients or if labile organic carbon is limiting bacterial growth in oligotrophic marine systems.

Pure culture and seawater culture methodology (Ammerman et al. 1984) have been used to address bacterial growth and C uptake. Previous experiments which investigated labile $\mathrm{C}$ uptake and bacterial growth efficiencies (BGE) used ${ }^{14} \mathrm{C}$-labeled substrates in short-term incubations and yielded $\mathrm{BGE}$ ranging from 50 to $95 \%$ (Williams 1970,1981 ). The shortcoming of this approach is that $\mathrm{C}$ uptake and BGE are based on the conversion of a few model compounds instead of a natural complex organic medium; thus, these estimates may be more representative of assimilation efficiency rather than growth efficiency (Bjørnsen \& Kuparinen 1991). Indeed, lower BGEs have been determined for bacteria grown on naturally occuring substrates. Several methods are used in which bacterial production is monitored along with the disappearance of substrate. One approach using naturally occurring substrate estimates DOC depletion indirectly by estimating changes in respiration in a series of parallel incubations in gas-tight bottles (Bjørnsen 1986, Hopkinson et al. 1989, Bjørnsen \& Kuparinen 1991, Coffin et al. 1993, Biddanda et al. 1994, Hansell et al. 1995). A second approach monitors DOC depletion directly by measuring changes in substrate concentrations (Kirchman et al. 1991, Kroer 1993, Zweifel et al. 1993) from a single large volume incubation chamber, which helps minimize bottle effects. However, little work has been conducted to address BGEs and DOC utilization in oligotrophic marine systems. In the case of the latter approach this is largely due to the difficulty in achieving high precision in the DOC anaiysis. Recent work with ine high temperature combustion (HTC) method has resulted in improved accuracy and precision in the determination of DOC (Benner \& Strom 1993, Peltzer \& Brewer 1993, Sharp et al. 1993, 1994) and has allowed the detection of small changes in the bulk DOC pool (Carlson et al. 1994, Carlson \& Ducklow 1995, Peltzer \& Hayward in press).

In the present study, we used seawater cultures (Ammerman et al. 1984) to investigate bacterial growth and DOC utilization in oligotrophic seawater. We directly measured changes in DOC concentrations together with changes in several bacterial parameters including thymidine and leucine incorporation, cell abundance, and cell volume. The objectives were: (1) to test the sensitivity of the HTC method for detecting small changes in the bulk DOC pool; (2) to obtain estimates of available DOC in the bulk pool and the BGE with which it was utilized by natural assemblages of oligotrophic bacterioplankton grown in unamended seawater; and (3) to determine how inorganic and organic nutrient enrichments affected bacterial growth and DOC utilization.

\section{METHODS}

Seawater culture preparation. Oligotrophic seawater was collected from several stations between Bermuda and Hydrostation $\mathrm{S}\left(32^{\circ} 10^{\prime} \mathrm{N}, 64^{\circ} 30^{\prime} \mathrm{W}\right)$ in July 1992, October 1992, March 1993, July 1993 and January 1994. All stations were located 3 to 12 miles off Bermuda in water at least $1000 \mathrm{~m}$ deep. Water was collected from a depth of approximately $10 \mathrm{~m}$ using 12 I Niskin bottles equipped with epoxy coated springs on a CTD (conductivity, temperature, depth probe) rosette or by using GO-FLO bottles on Kevlar line (both bottle types were General Oceanics, Miami, Florida, USA). Upon recovery, seawater was transferred to polycarbonate carboys via non-contaminating Teflon tubing. All carboys, Teflon tubing, and filtration devices were washed in $5 \% \mathrm{HCl}$ and rinsed with copious amounts of Millipore Q-Water (Milli-Q) prior to each experiment.

All seawater cultures, except the March 1993 experiment, which was a whole water treatment, were prepared by inoculating $0.22 \mu \mathrm{m}$ filter sterilized seawater with either whole (unfiltered) water, or a $0.8 \mu \mathrm{m}$ filtered inoculum at a dilution of 0 to $90 \%$ (see Table 1 ). Preparation of the $0.22 \mu \mathrm{m}$ filtrate began within $2 \mathrm{~h}$ of collection. To minimize cell breakage and contamination, all filtrates were generated by gentle gravity filtration though Nuclepore Membra-Fil filters and a $142 \mathrm{~mm}$ plastic filtration manifold. The potential organic and inorganic contamination from the membrane filters was minimized by flushing the filters with approximateiy 1.5 to $\hat{Z}$ i of iviiii- $Q$ water and approximately 21 of sample water before filtrate collection. The 10 l polycarbonate collection carboys were rinsed several times with filtrate after the filter had been well flushed. After 20 to 251 of $0.22 \mu \mathrm{m}$ filtrate had been generated, the water was distributed to respective carboys (Table 1) and inoculated. This process generally took 6 to $8 \mathrm{~h}$.

Cultures of 5 to 10 l were incubated in polycarbonate carboys in the dark at in situ temperatures and swirled frequently. All cultures, except those used in July and 
Table 1. Experimental parameters for Sargasso Sea DOC utilization/seawater culture from 1992 to 1994 . All cultures were incubated in the dark. October 1992 experiments included 2 culture preparation treatments: a $0.8 \mu \mathrm{m}$ filtrate culture and a culture in which the $0.8 \mu \mathrm{m}$ inoculum was diluted with particle-free water. -: not applicable

\begin{tabular}{|c|c|c|c|c|c|c|c|}
\hline Expt date & Treatment & $\begin{array}{c}\text { Final } \\
\text { concentration } \\
\text { (nominal) }\end{array}$ & $\begin{array}{l}\text { Inoculum } \\
\text { type }\end{array}$ & $\begin{array}{c}\% \text { inoculum } \\
\text { diluted with } \\
\text { particle-free water }\end{array}$ & $\begin{array}{c}\text { Incubation } \\
\text { temp. } \\
\left({ }^{\circ} \mathrm{C}\right)\end{array}$ & $\begin{array}{l}\text { Time until } \\
\text { end of log } \\
\text { phase (h) }\end{array}$ & $\begin{array}{c}\text { Expt } \\
\text { duration } \\
\text { (h) }\end{array}$ \\
\hline Jul 1992 & $\begin{array}{l}\text { Control } \\
\mathrm{NH}_{i} \\
\text { DFAA } \\
\text { Glucose }\end{array}$ & $\begin{array}{l}- \\
0.25 \mu \mathrm{MN} \\
30 \mu \mathrm{MC} \\
50 \mu \mathrm{MC}\end{array}$ & $\begin{array}{l}0.8 \mu \mathrm{m} \\
0.8 \mu \mathrm{m} \\
0.8 \mu \mathrm{m} \\
0.8 \mu \mathrm{m}\end{array}$ & $\begin{array}{l}90 \\
90 \\
90 \\
90\end{array}$ & $\begin{array}{l}23-25 \\
23-25 \\
23-25 \\
23-25\end{array}$ & $\begin{array}{l}41 \\
41 \\
31 \\
31\end{array}$ & $\begin{array}{l}180 \\
180 \\
180 \\
180\end{array}$ \\
\hline Oct 1992 & $\begin{array}{l}0.8 \text { filtrate } \\
90 \% \text { diluted }\end{array}$ & - & $\begin{array}{l}0.8 \mu \mathrm{m} \\
0.8 \mu \mathrm{m}\end{array}$ & $\begin{array}{r}0 \\
90\end{array}$ & $\begin{array}{l}23 \\
23\end{array}$ & $\begin{array}{l}- \\
-\end{array}$ & $\begin{array}{l}87 \\
87\end{array}$ \\
\hline Mar 1993 & Whole water & - & Whole water & 0 & 19.5 & 94 & 216 \\
\hline Jul 1993 & $\begin{array}{l}\text { Control } \\
\text { Glucose } \\
\text { DFAA } \\
\text { Algal lysate }\end{array}$ & $\begin{array}{l}20 \mu \mathrm{M} \mathrm{C} \\
20 \mu \mathrm{MC} \\
20 \mu \mathrm{MC}\end{array}$ & $\begin{array}{l}0.8 \mu \mathrm{m} \\
0.8 \mu \mathrm{m} \\
0.8 \mu \mathrm{m} \\
0.8 \mu \mathrm{m}\end{array}$ & $\begin{array}{l}80 \\
80 \\
80 \\
80\end{array}$ & $\begin{array}{l}26 \\
26 \\
26 \\
26\end{array}$ & $\begin{array}{l}- \\
48 \\
57 \\
57\end{array}$ & $\begin{array}{l}180 \\
180 \\
180 \\
180\end{array}$ \\
\hline Jan 1994 & $\begin{array}{l}\text { Control } \\
\mathrm{NH}_{4} \\
\mathrm{PO}_{4} \\
\text { Glucose }\end{array}$ & $\begin{array}{c}- \\
1 \mu \mathrm{M} \mathrm{N} \\
0.1 \mu \mathrm{M} \mathrm{P} \\
10.5 \mu \mathrm{M} \mathrm{C}\end{array}$ & $\begin{array}{l}\text { Whole water } \\
\text { Whole water } \\
\text { Whole water } \\
\text { Whole water }\end{array}$ & $\begin{array}{l}70 \\
70 \\
70 \\
70\end{array}$ & $\begin{array}{l}20 \\
20 \\
20 \\
20\end{array}$ & $\begin{array}{l}85 \\
85 \\
85 \\
52\end{array}$ & $\begin{array}{l}111 \\
111 \\
111 \\
111\end{array}$ \\
\hline
\end{tabular}

October 1992 experiments, were incubated at in situ temperatures. July and October 1992 cultures were incubated at room temperature, which was $\pm 2{ }^{\circ} \mathrm{C}$ of in situ temperatures. Samples were drawn periodically over 4 to $5 \mathrm{~d}$ through the carboy spigots.

Enrichment experiments. Final concentrations of organic and inorganic enrichments are reported in Table 1 . Since our primary objective was to measure changes in bulk DOC rather than individual compounds, we added organic carbon to seawater media in concentrations of 10 to $50 \mu \mathrm{M} \mathrm{C}$ to ensure that changes in bulk DOC would be measurable. The final concentration of DOC after additions was less than twice the ambient concentration of DOC, however the final concentrations of individual compounds such as glucose and amino acids were much greater than their ambient concentrations. The dissolved free amino acid (DFAA) treatments contained a mixture of leucine, glycine, phenylalanine, arginine, proline, threonine, alanine, histidine, tyrosine, serine, isoleucine, valine, asparagine, lysine, and methionine in equal molar concentrations. The mixture of amino acids (AA) was similar to commercial AA standard mixtures (Pierce, Rockford, Illinois, USA) (Shiah \& Ducklow 1994). The AA concentrations added to the culture are reported in carbon units as determined by HTC. The algal lysate, used in the July 1993 experiment, was prepared from a culture of Isochrysis galbana grown on F/2 medium and harvested at stationary growth phase. The cells were placed into several centrifuge tubes and spun at $1000 \mathrm{rpm}(\approx 90 \times g)$ for $20 \mathrm{~min}$. The supernatant was decanted and the pellet was resuspended in low carbon isotonic solution. This rinse procedure was conducted 3 times with each tube to minimize nutrient carry-over from media. Following the last rinse, the pellets were frozen at $-20^{\circ} \mathrm{C}$ to freeze-fracture the cells. The pellets were combined into 1 centrifuge tube, thawed, and resuspended in isotonic solution. The majority of cellular debris was removed by centrifugation at $14000 \mathrm{rpm}(16000 \times \mathrm{g})$ for $10 \mathrm{~min}$, and the supernatant was used as the primary algal lysate. The concentration of organic enrichment used in the July 1993 experiment was determined by HTC prior to the experiment, ensuring that cultures were enriched with the same $C$ concentration of varying quality.

The $C: N$ ratios of the DFAA and algal lysate supplement were determined in triplicate by soaking a combusted GF/F filter in the primary stock solutions. The elemental composition was determined by a Control Equipment Corporation 440 elemental analyzer (Lowell, Massachusetts, USA). The C:N ratios, based on atomic ratios, for DFAA and algal lysate supplement were $2.6 \pm 0.74$ and $19.47 \pm 6.4$, respectively.

Bacterial and flagellate abundance and bacterial biovolume. Acridine orange (final concentration $0.005 \%$; Hobbie et al. 1977) was used to enumerate bacteria. Samples were preserved with particle-free $25 \%$ glutaraldehyde (final concentration of $1.0 \%$ ) and stored at $4^{\circ} \mathrm{C}$ until slide preparation, which was within $24 \mathrm{~h}$ of sampling. Details of slide preparation, cell enumeration and biovolume estimates are presented in Carlson et al. (1995). At least 200 cells per slide were counted and analyzed for bacterial biovolume and at least 125 fields were counted to estimate flagellate abundance. Cell volumes were calculated using the algorithm of Baldwin \& Bankston (1988) and converted to biomass 
by using a carbon conversion factor (CCF) of $120 \mathrm{fg}$ $\mu \mathrm{m}^{-3}$ (Watson et al. 1977, Ducklow \& Carlson 1992). This CCF lalls in the midrange 80 to $220 \mathrm{fg} \mathrm{\mu m}^{-3}$ estimated by Gundersen et al. (1994) for bacterioplankton in the Sargasso Sea near Bermuda.

Specific growth rates were calculated from 2 properties: one based on changes in cell abundance and the other on changes in cell biomass. Cell biomass equaled

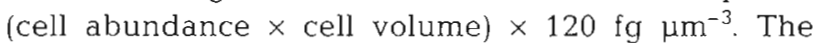
natural $\log$ of cell abundance or cell biomass was plotted vs time. The slope of the logarithmic portion of this curve is equal to the specific growth rate. The lag portion of the curves was ignored for the specific growth rate calculation, and the end of logarithmic growth was determined as the maximum value before the curve became stationary or declined.

Bacterial carbon production was considered to be the increase in cell carbon from the initial time point to the last point in logarithmic growth. The bacterial carbon production rates were determined by linear regression analysis of the increase in bacterial carbon from timezero $\left(t_{0}\right)$ through the end of the logarithmic growth phase (data were not log transformed). Coefficients of determination $\left(\mathrm{r}^{2}\right)$ varied from 0.714 to $0.975(\mathrm{n}=12)$, and all slopes were significant at the $0.05 \%$ significance level.

${ }^{3} \mathrm{H}$-thymidine and ${ }^{3} \mathrm{H}$-leucine incorporation. ${ }^{3} \mathrm{H}$ thymidine incorporation (Fuhrman et al. 1980, Fuhrman \& Azam 1982) and ${ }^{3} \mathrm{H}$-leucine incorporation (Kirchman et al. 1985) were used as sensitive indicators of changes in bacterial growth within the seawater cultures. The procedures followed those of Ducklow et al. (1993). Duplicate or triplicate incubations were amended with methyl [ ${ }^{3} \mathrm{H}$-methyl] thymidine (Amersham, specific activity $>80 \mathrm{Ci} \mathrm{mmol}^{-1}, 10 \mathrm{nM}$ final conc.) or ${ }^{3} \mathrm{H}$-leucine (Amersham, specific activity $>140 \mathrm{Ci} \mathrm{mmol}^{-1}, 20 \mathrm{nM}$ unlabelled and $1 \mathrm{nM}$ labelled final concentration); further details are presented in Carlson et al. (1995).

Dissolved organic carbon. To avoid potential contamination from filtration, samples were drawn directly from the carboy's spigot into combusted $40 \mathrm{ml}$ vials (Wheaton \#224833). The vials were rinsed with sample several times, filled $3 / 4$ full, capped with Teflon-faced silicone septa and open-top caps, and sealed with Tefilon iape. Sampies were quick frozen and stored at $-20^{\circ} \mathrm{C}$ until analyzed at Horn Point Environmental Laboratory (HPEL). Details of vial preparation are discussed in Carlson \& Ducklow (1995).

All DOC samples were analyzed by the HTC method using a modified Dohrmann DC-190 (Rosemount Analytical Inc., Santa Clara, California, USA). Detalls of the machine's configuration and operating parameters are discussed in Carlson \& Ducklow (1995) and Sharp et al. (1994). Briefly, $100 \mu$ of sample was injected manually into a quartz combustion tube packed with
CuO wire, Pt gauze and 1 to $5 \%$ Pt on alumina catalyst and heated to 720 to $780^{\circ} \mathrm{C}$. The temperature was reduced to $720^{\circ} \mathrm{C}$ to extend the operating life of the combustion tube. The temperature change had no effect on the final value of DOC concentration (data not shown). The resulting $\mathrm{CO}_{2}$ was detected with a LiCor $6252 \mathrm{CO}_{2}$ analyzer, and the signal was integrated with chromatographic software (Dynamax Macintegrator I version 1.3; Rainin Inst.).

Extensive conditioning of the combustion tube was essential to minimize the machine blank (Benner \& Strom 1993). The combustion tube was conditioned by increasing the temperature to $800^{\circ} \mathrm{C}$ for at least $24 \mathrm{~h}$ and flushing the tube repeatedly with low carbon water (LCW) injections until a total blank was reduced to approximately $10 \mu \mathrm{M} \mathrm{C}$. The highly pure LCW was generated from HPEL's Milli-Q water system and independently determined to contain approximately $3 \mu \mathrm{M}$ C (J. H. Sharp pers. comm.). The analysis was standardized daily with a 4 -point calibration curve of glucose solution in LCW. The high purity LCW was injected after the calibration curve and periodically throughout a daily run to monitor the instrument blank and performance.

In order to avoid the small error associated with the instrumental day-to-day variability, all samples generated from one experimental treatment were run on the same day. Analysis of utilization experiment samples required high precision and stable baseline performance from the HTC machine. This was attained by conditioning the machine for several days with deep seawater samples. Upon achieving stability, frozen samples were thawed at room temperature and $85 \%$ $\mathrm{H}_{3} \mathrm{PO}_{4}$ was added to original sample vials $(10 \mu \mathrm{l} / 10 \mathrm{ml})$. Immediately prior to injection, samples were sparged with $\mathrm{CO}_{2}$-free oxygen for at least $10 \mathrm{~min}$ to dissolve all the precipitate that had formed during freezing and to remove inorganic carbon. A volume of $100 \mu \mathrm{l}$ was injected through a septum-less port 3 to 5 times per sample. DOC concentrations were determined by the following equation:

$\mu \mathrm{MC}=$

Average sample area - Average machine blank area Slope of standard curve

DOC consumption rates were determined by linear regression analysis of the decrease in DOC concentration over the logarithmic phase of growth. Coefficients of determination $\left(\mathrm{I}^{2}\right)$ for all fast-growing cultures varied from 0.853 to $0.994(n=11)$ and slopes were significant. A value of 0.594 was generated for the March 1993 culture in which the slope was not significant at the 0.05 level.

Bacterial growth efficiency. To take advantage of all measured points along the curves of bacterial growth 
and DOC removal, the BGE was calculated by the following formula:

$$
\mathrm{BGE}=\frac{\text { Bacterial production }}{-(\text { DOC consumption })} \times 100
$$

where bacterial production is the slope of the linear regression of bacterial $\mathrm{C}$ versus time and DOC consumption is the slope of the linear regression of $\mathrm{DOC}$ removed versus time. DOC concentrations were corrected for bacterial biomass. The BGE was calculated for both the log phase of growth and the entire incubation.

Data analysis. Statistical analysis including analysis of covariance (ANCOVA) and linear regression (Model 1) was performed using Super ANOVA (Abacus Concepts, Inc, Berkeley, California, USA, 1989). Parameters are described as significantly different when the significance level of $\leq 0.05$ was met. The standard errors associated with bacterial production rates and DOC consumption rates were determined from the linear regressions of the measured parameters versus time. Due to logistical constraints only 1 culture could be grown for each treatment within an experiment leading to problems associated with pseudoreplication (Hulbert 1984). However, the experimental design, which compared labile $\mathrm{C}$ amendments to control cultures, was repeated 3 separate times, thus replicating the experiment, and all experiments produced a similar trend of enhanced growth due to the addition of labile carbon as compared to a control (see 'Results').

\section{RESULTS}

\section{Contamination due to seawater culture preparation}

Preliminary experiments demonstrated that a significant amount of DOC can be leached from the Nuclepore Membra-Fil filters. However, this contamination can be minimized by flushing filter with copious amounts of Milli-Q water prior to sample collection (Fig. 1).

DOC concentrations in cultures for July 1992, October 1992, March 1993 and July 1993 did not increase during preparation compared to samples taken from the water column at the time of collection (Fig. 2). These results indicate that with proper conditioning of filters and incubation vessels, DOC contamination on the $\mu \mathrm{M} C$ scale can be eliminated. However, several studies (Fuhrman \& Bell 1985, Kirchman et al. 1989, Keil \& Kirchman 1991) have demonstrated that dissolved primary amine concentrations may increase from gravity filtration due to cell breakage and, thus, contamination of selected dissolved compounds due to filtration cannot be ruled out.
In order to place the initial culture DOC levels in the context of oceanic ranges, we present surface DOC concentrations from oceanic stations in the vicinity of the Bermuda Atlantic Time-series Station $\left(31^{\circ} 10^{\prime} \mathrm{N}, 64^{\circ} 10^{\prime} \mathrm{W}\right.$; BATS) in Fig. 2. The average concentration for the BATS mixed layer was $\sim 67$ to $69 \mu \mathrm{M} \mathrm{C}$ in all seasons except winter 1993. These winter 1993 samples were collected during a mixing event in which deeper, low carbon water was entrained into the surface resulting in a dilution of the surface DOC water to a concentration of $\sim 64 \mu \mathrm{M}$ C (see Carlson \& Ducklow 1994). The water collected for the July 1992, March 1993, and January 1994 culture experiments all had higher initial concentrations $\left(t_{0}\right)$ compared to reference field samples collected near the BATS station (Fig. 2). Seawater used for these experiments was collected from stations located between Bermuda and Hydrostation S. The reasons for high initial DOC concentrations in the seawater collected for culture work are unknown, but Fig. 2 shows that higher concentrations were not due to post-collection contamination. This increase may have been a result of contamination from the collection bottles during initial collection; however, it is unlikely due to the fact that the bottles were flushed thoroughly by moving the bottles up and down in an open position through approximately 100 to $250 \mathrm{~m}$ of the water column prior to triggering the bottle closed. The elevated DOC concentrations may be a result of mesoscale features which affected spatial variability in DOC stocks and DOC source-sink relationships.

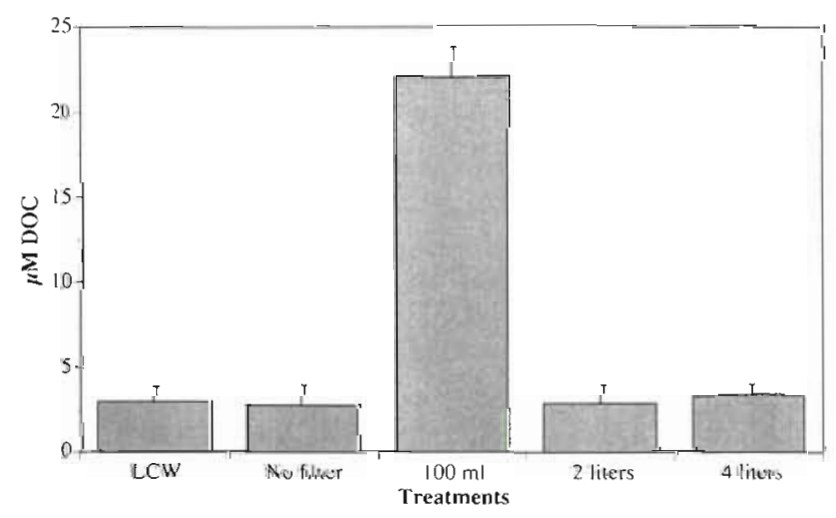

Fig. 1 Nuclepore Membra-Fil filters can contaminate the filtrate with DOC if not conditioned properly. Low carbon water (LCW) was used as a reference blank value. The no filter treatment represents the DOC concentration of water passing through the filter holder and tubing without a filter present. The $100 \mathrm{ml}, 2 \mathrm{l}$ and $4 \mathrm{l}$ treatments refer to the amount of water flushed through the filter membrane before water was sampled for HTC analysis. Error bars represent 1 SD from the mean of 3 injections 


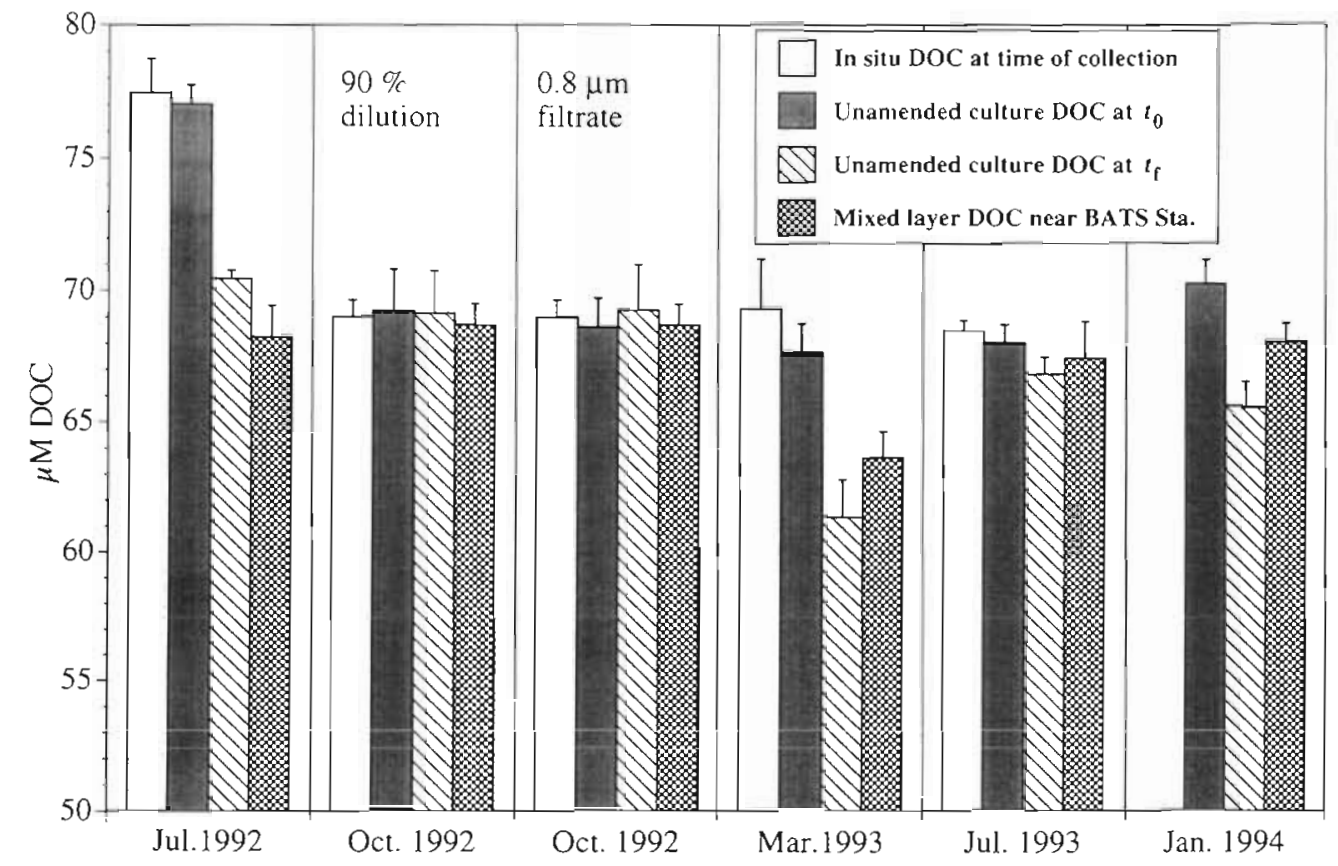

Fig. 2. DOC samples taken from the water column at the time of media collection are compared to the control DOC concentration after media preparation $\left(t_{0}\right)$. DOC concentrations at $t_{0}$ and at the end of the culture $\left(t_{1}\right)$ are also compared for each experiment. $90 \%$ dilution and $0.8 \mu \mathrm{m}$ filtrate headings refer to the experimental set up for the October 1992 cultures (see Table 1 ). Concentration of DOC found in the mixed layer collected from the BATS site also shown. There was significant DOC removal from $t_{0}$ to $t_{\mathrm{t}}$ only in the July 1992, March 1993, and January 1994 experiments where the initial DOC culture concentrations were greater than the DOC concentration within the BATS mixed layer. Error bars represent 1 SD. Data presented are from cultures conducted in July 1992, October 1992, March 1993, July 1993, and January 1994

\section{DOC utilization and bacterial growth in unamended seawater cultures}

Cultures that demonstrated high growth also exhibited significant removal of bulk DOC (slope significant at the 0.05 level) (Fig. 3A). High bacterial growth and measurable DOC removal only occurred in cultures with initial DOC values higher than BATS mixed layer concentrations (Figs. 2 \& 3). The growing seawater cultures in the July 1992, March 1993, and January 1994 experiments all demonstrated a classic sigmoidal growth curve that began with a lag phase of 10 to $20 \mathrm{~h}$, was followed by a period of logarithmic growth, and terminated with a stationary growth phase (Fig. 3A). DOC utilization for these cultures followed a general pattern of rapid DUC removal during the lag phase and logarithmic growth, followed by a stabilizing period in which DOC utilization became insignificant during stationary growth phase. By the end of the experiments (111 to $216 \mathrm{~h}$ ), DOC had been drawn down to concentrations similar to or slightly lower than those in the BATS mixed layer (Fig. 2). Although rates of bacterial production and DOC utilization varied between seasons, the fraction of DOC consumed through the end of the logarithmic growth period was 6 to $7 \%$ for all fast-growing cultures (Table 2). The
BGE for cultures able to grow on the slightly enhanced DOC levels in unamended seawater media averaged $14 \pm 6 \%$ through log phase or $12 \pm 6 \%$ over the entire incubation period. In cultures where DOC concentrations were similar to BATS mixed layer concentrations bacterial growth was low or not significant and DOC removal could not be resolved (Figs. $2 \& 3 B$, Table 2).

\section{Effects of nutrient additions}

The effects of nutrient additions on bacterial growth and BGE were investigated by adding several inorganic and organic nutrients to a series of seawater cultures. A total of 3 complete nutrient enrichment experiments, each containing 3 nutrient treatments and an unamended control, were conducted in July 1992, July 1993, and January 1994 (Table 1). The time course responses of bacterial $\mathrm{C}$, flagellate abundance, ${ }^{3} \mathrm{H}$-thymidine incorporation, and ${ }^{3} \mathrm{H}$-leucine incorporation to each nutrient supplement are presented in Fig 4. Growth patterns of bacterial $C$ were similar to familiar batch culture patterns (described above) for all treatments except the July 1993 control, which did not grow well relative to other treatments. Bacter- 
Fig. 3. Time course response of bacterial carbon ( $)$ and DOC concentration $(0)$ in unamended seawater cultures. (A) Cultures that demonstrated measurable growth utilized a significant portion of the bulk DOC pool. (B) Cultures that showed minimal growth did not significantly remove DOC
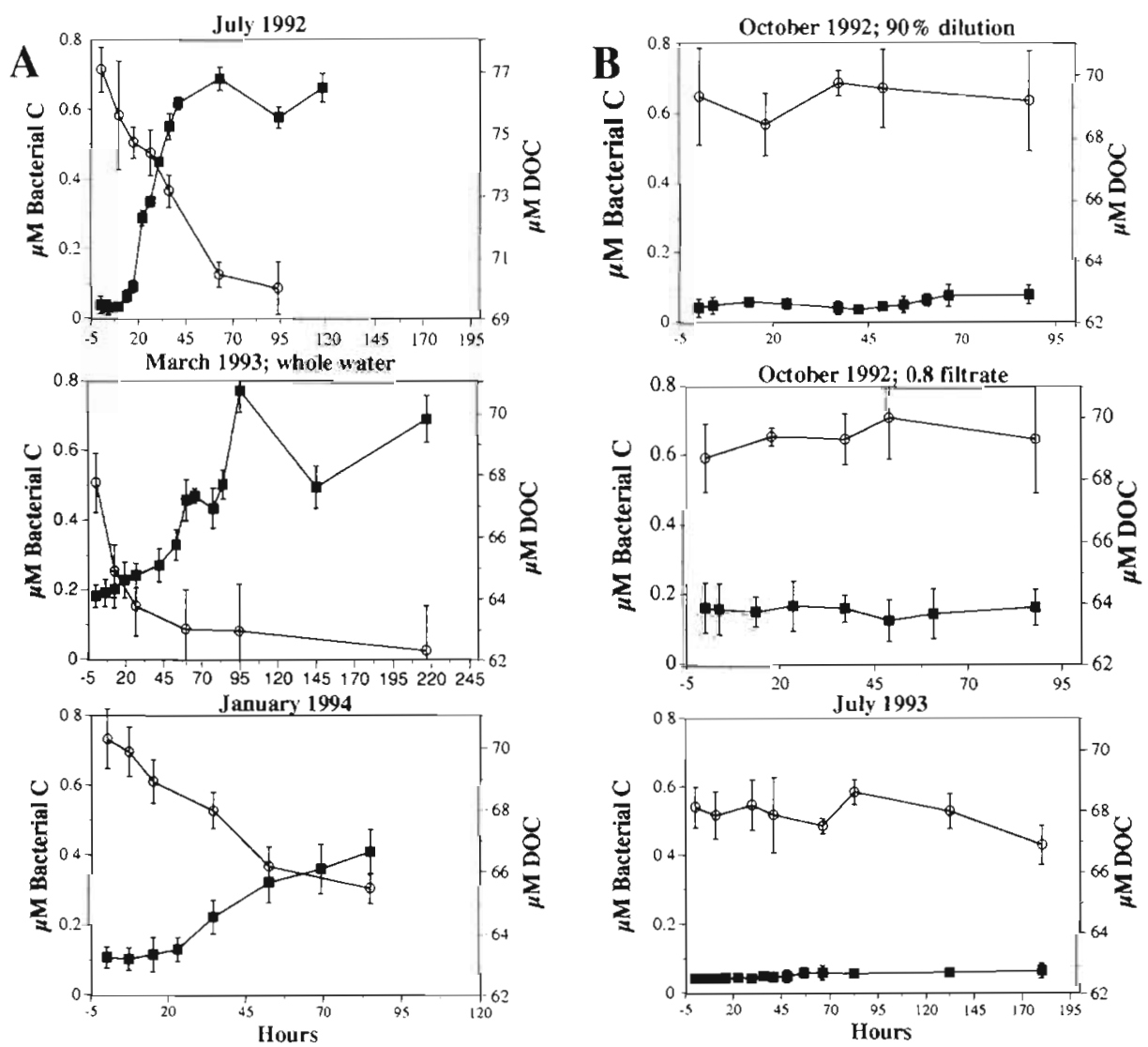

ial $C$ decreased in several treatments after stationary growth. However, grazer concentrations remained consistently low and appeared to have little effect on the dynamics of bacterial $C$ production for the first $100 \mathrm{~h}$ of culture growth (Fig. 4). Grazers increased after $100 \mathrm{~h}$ in only 4 of the 12 treatments.

Rates of ${ }^{3} \mathrm{H}$-thymidine and ${ }^{3} \mathrm{H}$-leucine incorporation varied greatly and were not coupled to changes in bac- terial carbon (Fig. 4A, C, D). ${ }^{3} \mathrm{H}$-leucine measurements could not be determined for DFAA treatments due to isotope dilution caused by the large addition of DFAA. The uncoupling between ${ }^{3} \mathrm{H}$-thymidine incorporation, ${ }^{3} \mathrm{H}$-leucine incorporation, and change in cellular biomass is evidence of unbalanced growth and has been discussed by several investigators (Chin-Leo \& Kirchman 1990, Bjørnsen \& Kuparinen 1991, Ducklow et al. 1992).

Table 2. Bacterial growth and DOC utilization for natural assemblages of bacterioplankton grown on oligotrophic seawater medium collected from the Sargasso Sea near Bermuda. ns: no significant change at the $5 \%$ significance level, -: no data

\begin{tabular}{|c|c|c|c|c|c|c|}
\hline \multirow{2}{*}{$\begin{array}{l}\text { Expt } \\
\text { Fast growth }\end{array}$} & \multirow[t]{2}{*}{$\begin{array}{c}\text { Bacterial production } \\
\text { rate }^{a} \\
\mu \mathrm{MCh^{-1 }}( \pm \mathrm{SE})\end{array}$} & \multirow[t]{2}{*}{$\begin{array}{c}\text { DOC consumption } \\
\text { rate }^{\mathrm{a}} \\
\mu \mathrm{MC} \mathrm{h}^{-1}( \pm \mathrm{SE})\end{array}$} & \multicolumn{2}{|c|}{$\%$ DOC consumed } & \multicolumn{2}{|c|}{$\begin{array}{c}\text { Growth efficiency } \\
\%( \pm \text { SE) } \\
\text { Log phase Entire incubation }\end{array}$} \\
\hline & & & & & & \\
\hline Jul 1992 & $0.016(0.002)$ & $0.101(0.01)$ & 6 & 9 & $19(2)$ & $9(3)$ \\
\hline Mar 1993 & $0.005(0.001)$ & $0.040(0.02)$ & 7 & 8 & $15(3)$ & $19(7)$ \\
\hline Jan 1994 & $0.003(0.001)$ & $0.059(0.01)$ & 7 & 7 & $7(1)$ & $7(2)$ \\
\hline \multicolumn{7}{|c|}{ Slow or no growth } \\
\hline Oct $1992 ; 90 \%$ & $0.0004(0.0001)$ & $-0.004(0.008)$ & ns & ns & - & - \\
\hline $\begin{array}{l}\text { Oct } 1992 ; \\
0.8 \text { um filtrate }\end{array}$ & $-0.00004(0.0002)$ & $-0.007(0.007)$ & ns & ns & - & - \\
\hline Jul 1993 & $0.0002(0.00002)$ & $0.004(0.003)$ & ns & ns & - & - \\
\hline
\end{tabular}


July 1992

A

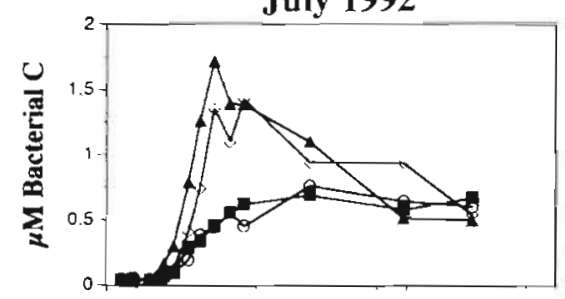

B

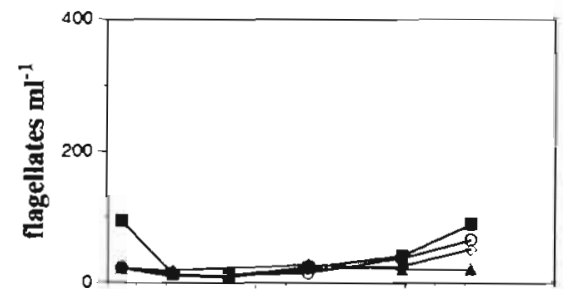

C

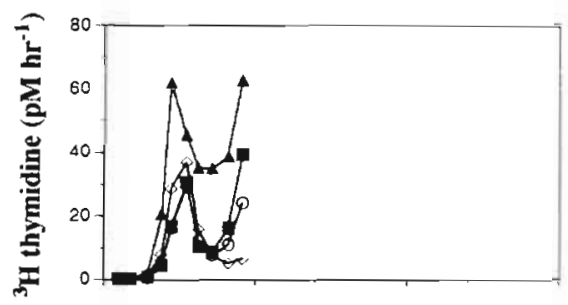

D

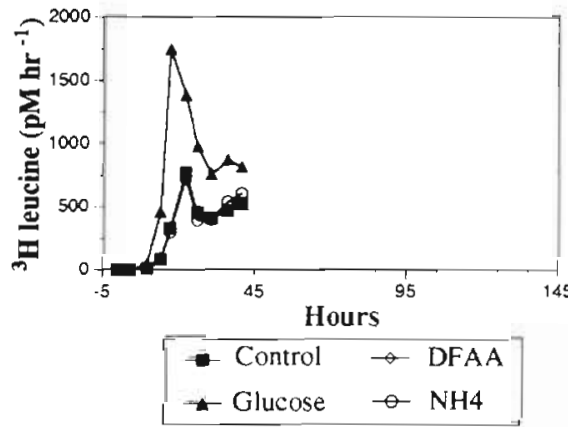

July 1993
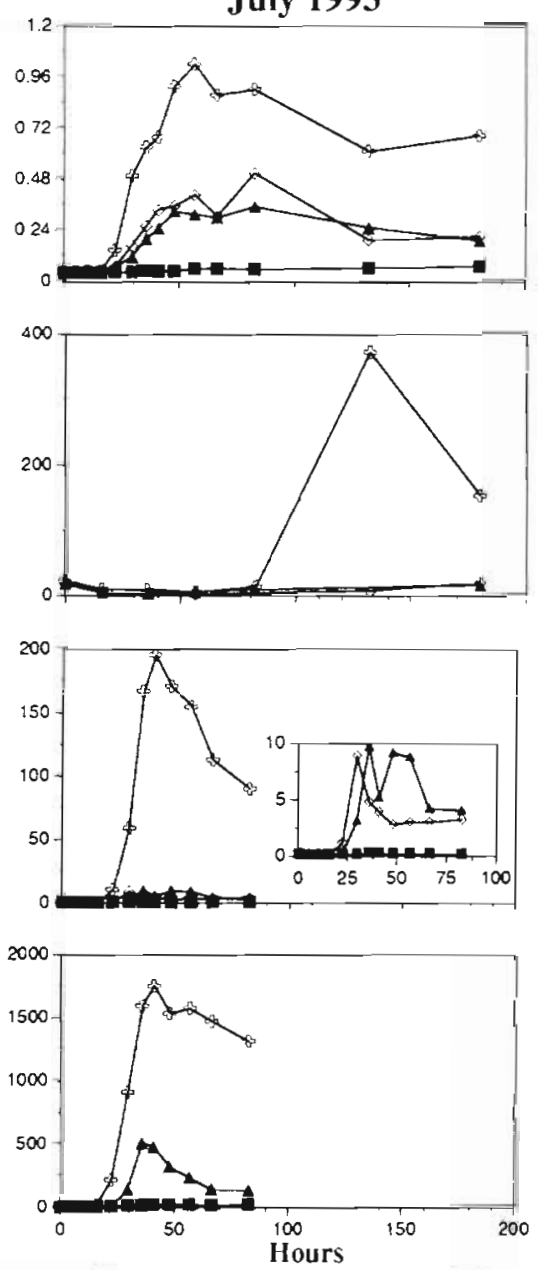

$\left[\begin{array}{l}- \text { Control } \rightarrow \text { DFAA } \\ \star \text { Glucose } \rightarrow \text { Algal lysate }\end{array}\right.$
January 1994
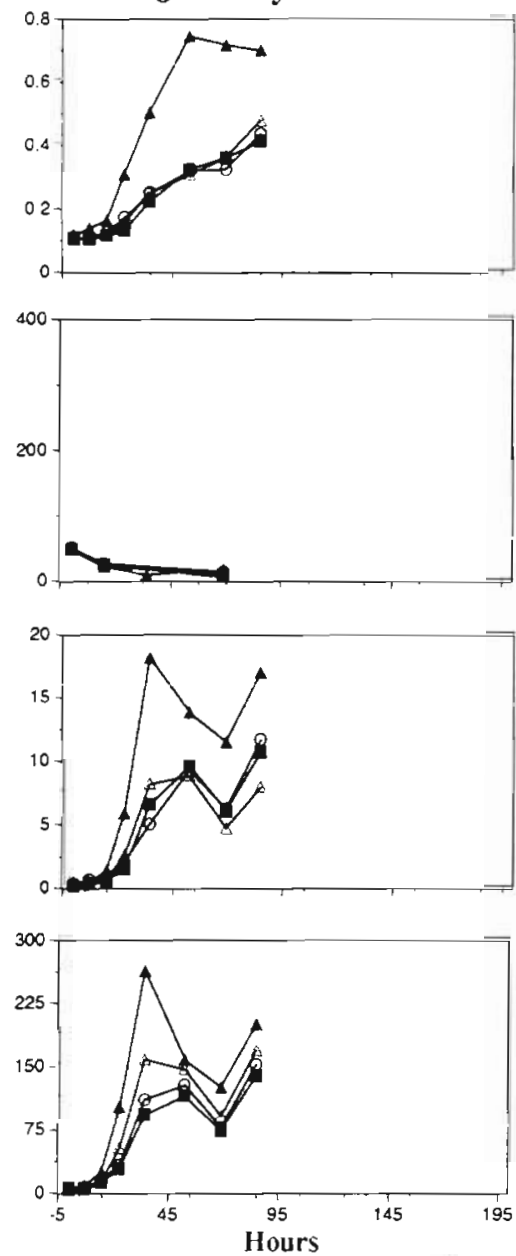

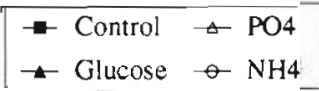

Fig. 4. Time course response of (A) bacterial C, (B) flagellates, (C) ${ }^{3} \mathrm{H}$-thymidine incorporation, and (D) ${ }^{3} \mathrm{H}$-leucine incorporation to nutrient enrichments in the July 1992, July 1993, and January 1994 experiments. The inset in the July $1993{ }^{3} \mathrm{H}$-thymidine panel is a rescaled plot of the glucose, DFAA, and control treatments

Difficulties in interpreting these dynamics led us to calculate bacterial $C$ production from direct measurements of bacterial counts and cell volumes. However, we found the radioactive tracer techniques useful in illustrating general trends between treatments (Fig. 4C, D). Except for the DFAA treatment in the July 1992 experiment, the DOM enrichments resulted in a greater incorporation of ${ }^{3} \mathrm{H}$-thymidine and ${ }^{3} \mathrm{H}$-leucine compared to inorganic or control treatments.

Estimates of bacterial abundance, biovolume, and cell carbon obtained from the last point in logarithmic growth for each treatment (Table 1) are compared to $t_{0}$ background values (represented by the horizontal lines) in Fig. 5. Cell abundance was only slightly greater than the control for glucose and DFAA substrate enrichments and significantly higher with the algal lysate treatment. Cell volume increased significantly as cultures progressed from lag phase to logarithmic growth and either stabilized or decreased as stationary growth was attained. The magnitude of this increase varied from experiment to experiment.

urganic treatments ylelded the larger ceil voiumes in all 3 experiments (Fig. 5) with little difference in the cell volume change between the control and inorganic $N$ or $P$ treatments. Changes in cell volume were accounted for by converting biovolume (cell abundance $x$ cell volume) to biomass via a conservative volumebased conversion factor $\left(120 \mathrm{fg} C \mu \mathrm{m}^{-3}\right)$. In all organic treatments, except the algal lysate treatment, bacterial $C$ was greatly enhanced above the control by changes in cell volume relative to changes in cell abundance (Fig. 5). 
Fig. 5. July 1992, July 1993, and January 1994 nutrient enrichment experiments. (A) Bacterial cell numbers, (B) bacterial cell volume, and (C) biomass were estimated from the last point in logarithmic growth. Horizontal line represents the initial value $t_{0}$ of the control treatment
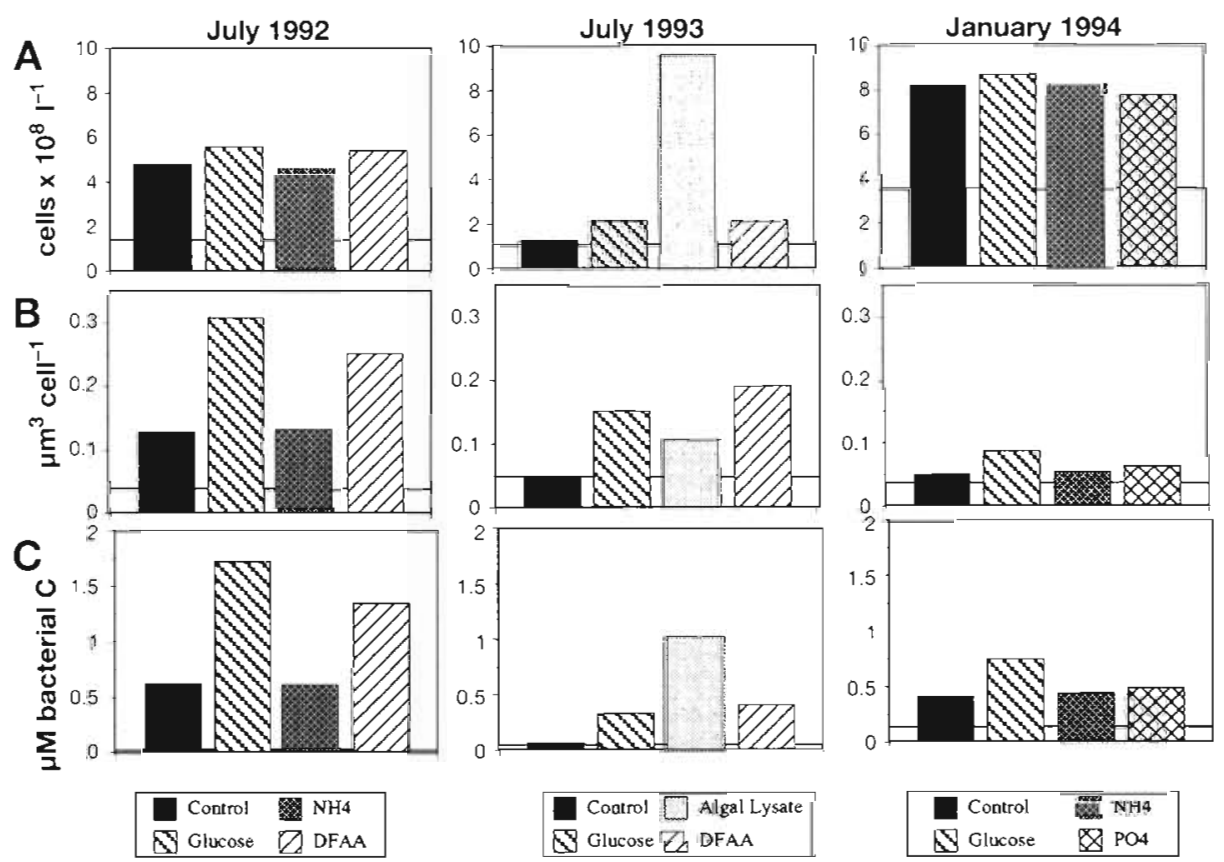

\section{July 1992 nutrient enrichment experiment}

In the July 1992 experiment, specific growth rates, bacterial $\mathrm{C}$ production, and DOC consumption rates were not significantly different in the control and $\mathrm{NH}_{4}$ treatments (Table 3; ANCOVA; $\mathrm{p}>0.05$ significance level) but were substantially enhanced by
DFAA and glucose supplements. The percentage enhancement over the control was calculated via the following formula:

$$
\begin{aligned}
& \% \text { enhancement over control }= \\
& \frac{\text { Treatment value }- \text { Control value }}{\text { Control value }} \times 100 \%
\end{aligned}
$$

Table 3. Estimates of bacterial growth, DOC utilization, and growth efficiency for nutrient enrichment experiments. Treatments with the same letters within an experiment indicate no significant difference between the slopes at the 0.05 significance level

\begin{tabular}{|c|c|c|c|c|c|c|c|}
\hline \multirow[t]{2}{*}{ Expt } & \multirow[t]{2}{*}{ Treatment } & \multicolumn{2}{|c|}{ Growth property } & \multirow{2}{*}{$\begin{array}{c}\text { Bacterial C } \\
\text { production rate } \\
\mu \mathrm{MC} \mathrm{h}^{-1}( \pm \mathrm{SE})\end{array}$} & \multirow{2}{*}{$\begin{array}{c}\text { DOC } \\
\text { consumption rate } \\
\mu \mathrm{MC} \mathrm{h}^{-1}( \pm \mathrm{SE})\end{array}$} & \multicolumn{2}{|c|}{ Growth efficiency } \\
\hline & & Abundance & Biomass ${ }^{b}$ & & & Log phase & Entire incubation \\
\hline \multirow[t]{4}{*}{ Jul 1992} & Control & $0.047 \mathrm{a}$ & $0.096 \mathrm{a}$ & $0.016(0.002) \mathrm{a}$ & $0.101(0.008) \mathrm{a}$ & $19(2)$ & $9(3)$ \\
\hline & $\mathrm{NH}_{4}$ & $0.045 \mathrm{a}$ & $0.097 \mathrm{a}$ & $0.016(0.002) \mathrm{a}$ & $0.108(0.004) \mathrm{a}$ & $17(2)$ & $6(3)$ \\
\hline & DFAA & $0.070 \mathrm{~b}$ & $0.176 \mathrm{~b}$ & $0.037(0.010) b$ & $0.216(0.007) \mathrm{b}$ & $21(6)$ & $1(1)$ \\
\hline & Glucose & $0.057 \mathrm{~b}$ & $0.165 \mathrm{~b}$ & $0.054(0.010) \mathrm{b}$ & $0.236(0.035) \mathrm{b}$ & $30(6)$ & $<1$ \\
\hline \multirow[t]{4}{*}{ Jul 1993} & Control & $0.002 \mathrm{a}$ & $0.003 \mathrm{a}$ & $1.6 \times 10^{-4}\left(2.0 \times 10^{-5}\right) a$ & $0.004(0.003) \mathrm{a}$ & - & $4(1)^{\circ}$ \\
\hline & Glucose & $0.024 \mathrm{~b}$ & $0.068 \mathrm{~b}$ & $0.006(0.001) \mathrm{b}$ & $0.148(0.013) \mathrm{b}$ & $4(1)$ & $1(1)$ \\
\hline & DFAA & $0.027 \mathrm{~b}$ & $0.060 \mathrm{~b}$ & $0.008(0.001) \mathrm{b}$ & $0.126(0.013) \mathrm{b}$ & $7(1)$ & $1(1)$ \\
\hline & Algal lysate & $0.057 \mathrm{c}$ & $0.071 \mathrm{~b}$ & $0.019(0.002) \mathrm{c}$ & $0.092(0.002) \mathrm{c}$ & $28(3)$ & $11(6)$ \\
\hline \multirow[t]{4}{*}{ Jan 1994} & Control & $0.011 \mathrm{a}$ & $0.019 \mathrm{a}$ & $0.004(0.001) \mathrm{a}$ & $0.059(0.007) \mathrm{a}$ & $7(1)$ & $7(2)$ \\
\hline & $\mathrm{NH}_{4}$ & $0.010 \mathrm{a}$ & $0.017 a$ & $0.004(0.001)$ & $0.077(0.016) \mathrm{a}$ & $5(1)$ & $6(2)$ \\
\hline & $\mathrm{PO}_{4}$ & $0.011 \mathrm{a}$ & $0.019 \mathrm{a}$ & $0.005(0.001) \mathrm{a}$ & $0.066(0.009) \mathrm{a}$ & $8(0)$ & $5(2)$ \\
\hline & Glucose & $0.017 \mathrm{~b}$ & $0.038 \mathrm{~b}$ & $0.013(0.001) \mathrm{b}$ & $0.154(0.015) b$ & $9(1)$ & $3(2)$ \\
\hline \multirow{4}{*}{\multicolumn{8}{|c|}{$\begin{array}{l}{ }^{a} \text { Growth rates were calculated from the slopes of the regression of ln cell numbers or ln biomass vs time during the loga- } \\
\text { rithmic growth phase. All units are } \mathrm{h}^{-1} \\
\text { b Biomass }=(\text { abundance } \times \text { mean cell volume }) \times\left(120 \mathrm{fg} \mathrm{C} \mathrm{Cm}^{-3}\right) \\
{ }^{c} \text { Rates of bacterial production and DOC removal were estimated from the slope of linear regression of bacterial C vs time and } \\
\text { DOC vs time through the end of logarithmic growth }\end{array}$}} \\
\hline & & & & & & & \\
\hline & & & & & & & \\
\hline & & & & & & & - Slope of the linear regression of DOC consumption was not significant at the 0.05 level; thus, BGE is not considered accurate \\
\hline
\end{tabular}
according to analysis of covariance (ANCOVA) 
DFAA and glucose treatments stimulated bacterial $C$ production by 131 and $237 \%$, respectively, and DOC consumption rates by 114 and $134 \%$, respectively, over the control (Table 3). Although cell abundances for the DFAA and glucose treatments were slightly higher than the control and $\mathrm{NH}_{4}$ treatments, the large increase in bacterial $C$ resulted from significant increase in cell volumes (Fig. 5). There were no significant differences between glucose and DFAA treatments with respect to specific growth rates, bacteria $\mathrm{C}$ production, or DOC consumption. BGE was higher for the organic enrichments, but only the glucose treatment was significantly greater than the control (Table 3).

DOC consumption was similar in both the $\mathrm{NH}_{4}$ and control treatments, where DOC concentrations decreased to approximately 69 to $70 \mu \mathrm{M} \mathrm{C}$ by the time the stationary growth phase was reached and did not vary significantly for the remainder of the incubation period (Fig. 6). As in the unamended cultures described above, DOC concentrations at the end of the incubation were similar to the BATS mixed layer concentrations for the $\mathrm{NH}_{4}$ and control treatments. In contrast, DOC consumption in both the DFAA and glucose treatments continued even after bacterial cell production ceased, but DOC consumption had not declined to the ambient level ( 67 to $69 \mu \mathrm{M} \mathrm{C}$ ) by the end of the experiment.

\section{July 1993 nutrient enrichment experiment}

The objective of the July 1993 experiment was to determine if the response to equal DOC additions (actual concentrations of added DOC ranged from 22 to $26 \mu \mathrm{M} \mathrm{C}$ ) of varying quality would affect the growth response and DOC consumption of a natural assemblage of oligotrophic bacterioplankton. Growth rates in all organically enriched cultures increased rapidly with significant increase in specific growth rates, bacterial $\mathrm{C}$ production, and DOC consumption compared to the control (Table 3, Fig. 7). The growth response to algal lysate was significantly greater than glucose and DFAA treatments by approximately $216 \%$, yet the DOC consumption rate was 37 and $27 \%$ lower, respectively (Table 3 ). As a result, BGE determined for the algal lysate treatment was highest. Changes in cell volume contributed less to bacterial $\mathrm{C}$ increase in the algal lysate treatment than in the glucose and DFAA treatments (Fig. 5).

As in the July 1992 experiment, DOC removal continued in the DFAA and glucose treatments even after bacterial C growth ceased (Fig. 7). However, DOC consumption stabilized at approximately $82 \mu \mathrm{M} \mathrm{C}$ in the stationary phase for the algal lysate treatment. These results indicate that only $7.5 \mu \mathrm{M} \mathrm{C}$ of the added $21.5 \mu \mathrm{M} C$ was readily available in ca $200 \mathrm{~h}$ of incubation. The remaining $14 \mu \mathrm{M} C$ must have represented
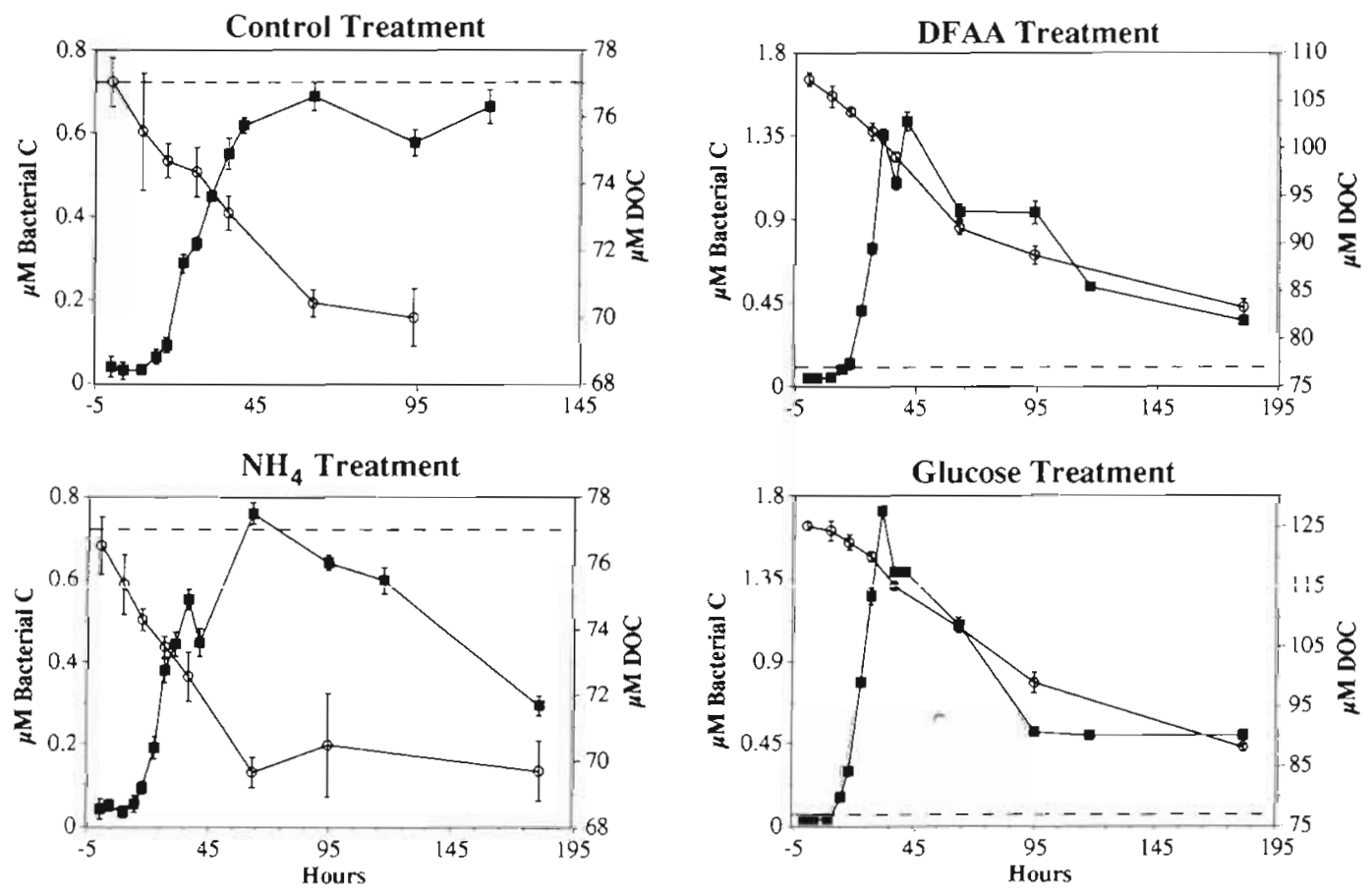

Fig. 6. July 1992 experiment. DOC concentration (o) and bacterial carbon ( $\mathbf{a}$ ) for various seawater cultures treatments including a control, $\mathrm{NH}_{4}$, glucose, and DFAA treatments. Dashed line represents the ambient DOC concentration at time of seawater collection. Error bars represent $1 \mathrm{SD}$ from the mean 
Fig. 7. July 1993 experiment. DOC concentration (o) and bacterial carbon (匹) for various seawater cultures treatments including a control, glucose, DFAA, and algal lysate treatments. Dashed line represents the ambient DOC concentration at time of seawater collection. Error bars represent $1 \mathrm{SD}$ from the mean
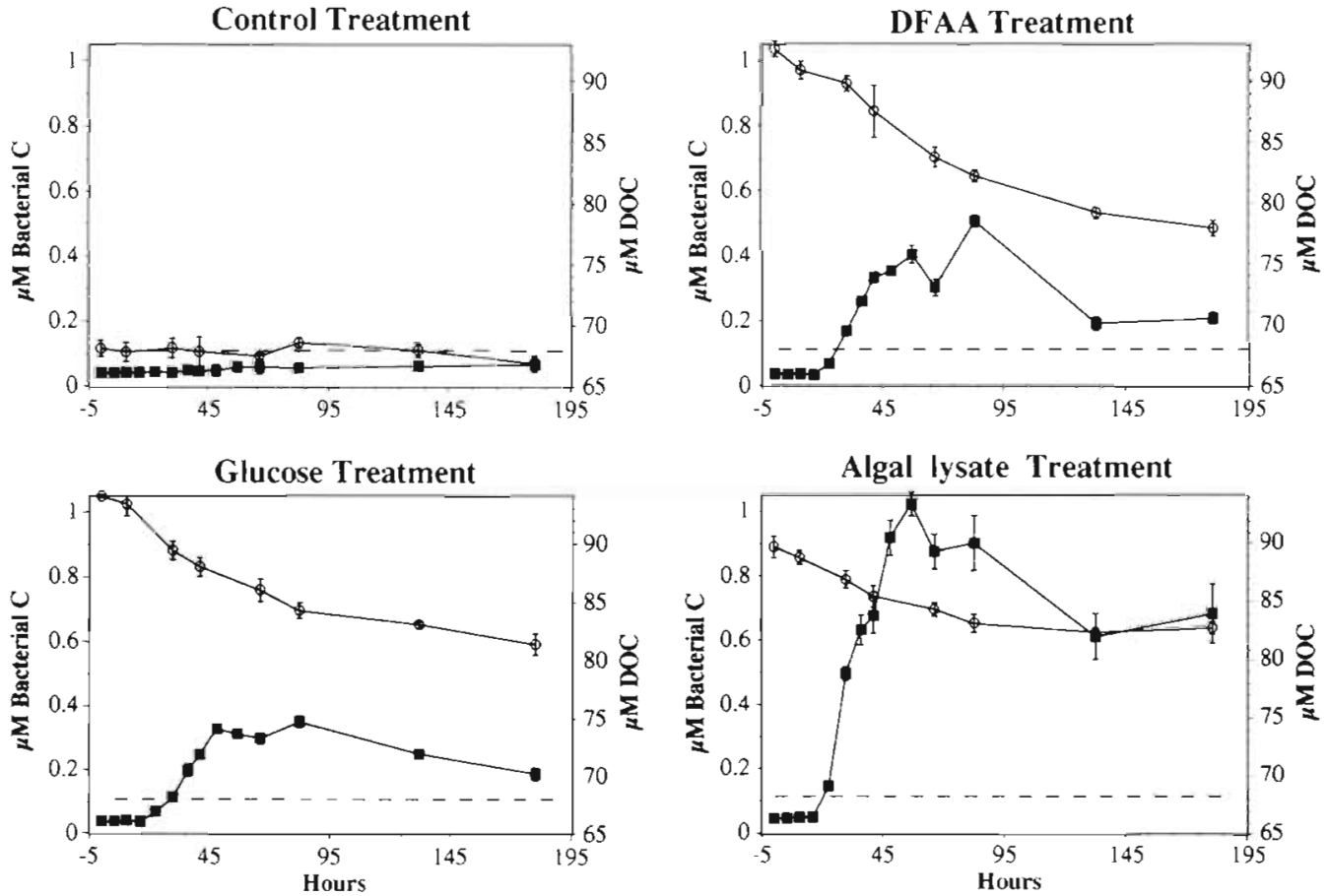

more refractory components that could not be oxidized on the time scale of this experiment. The algal lysate was a complex mixture of organic material; thus, a homogeneous lability of this material was not expected. Despite the lower percentage of available DOM in the algal lysate, the available portion was utilized more efficiently than glucose and DFAA enrichments.

\section{January 1994 nutrient enrichment experiment}

In the January 1994 experiment, the response of specific growth rates, bacterial $C$ production, and DOC utilization to the inorganic enrichment $\left(\mathrm{NH}_{4}\right.$ and $\mathrm{PO}_{4}$ ) was not significantly different from the control (ANCOVA; significance level of 0.05). However, the glucose supplement enhanced bacterial $\mathrm{C}$ production and DOC utilization by 225 and $161 \%$, respectively, over the control (Table 3, Fig. 8). The changes in cell volume were similar in the inorganic and control treatments (Fig. 5). The overall changes in cell volume were relatively small compared to previous experiments, yet the contribution of this change significantly enhanced bacterial C production in the glucose treatment (Fig. 5).

DOC utilization was similar in the control and inorganic treatments, decreasing linearly for the first $53 \mathrm{~h}$ and reaching an asymptote of 64 to $66 \mu \mathrm{M} \mathrm{C}$ by the stationary growth phase (Fig. 8). Note that in this experiment, DOC declined to below the initial ambient level in all treatments. The high DOC value detected for the last DOC time-point of the $\mathrm{PO}_{4}$ treatment was attributed to contamination and was disregarded. As in previous experiments DOC continued to decline in the glucose treatment throughout the entire incubation period (Fig. 8). BGE determined through logarithmic growth was highest for the glucose treatment. However, the glucose BGE was only significantly different from the $\mathrm{NH}_{4}$ treatment and not for the others. When BGE was determined for the entire incubation period, the glucose treatment had the lowest efficiency due to continued DOC removal after growth had ceased (Table 3).

\section{DISCUSSION}

\section{DOC utilization in unamended seawater cultures}

In the oceanic environment the production of 'fresh' DOC originates from in situ biological processes such as direct exudation from phytoplankton (Lancelot 1979. Goldman et al. 1992), zooplankton excretion and egestion (Lampert 1978, Nagata \& Kirchman 1992), particle hydrolysis (Smith et al. 1992), and cell lysis from viral infection (Proctor \& Fuhrman 1990, Fuhrman 1992). The application of size fractionation and dilution techniques combined with incubations in the dark minimizes these potential sources of DOC production in culture experiments (except for viral impact). Thus, our experimental design forces an uncoupling both of DOC production from consumption 

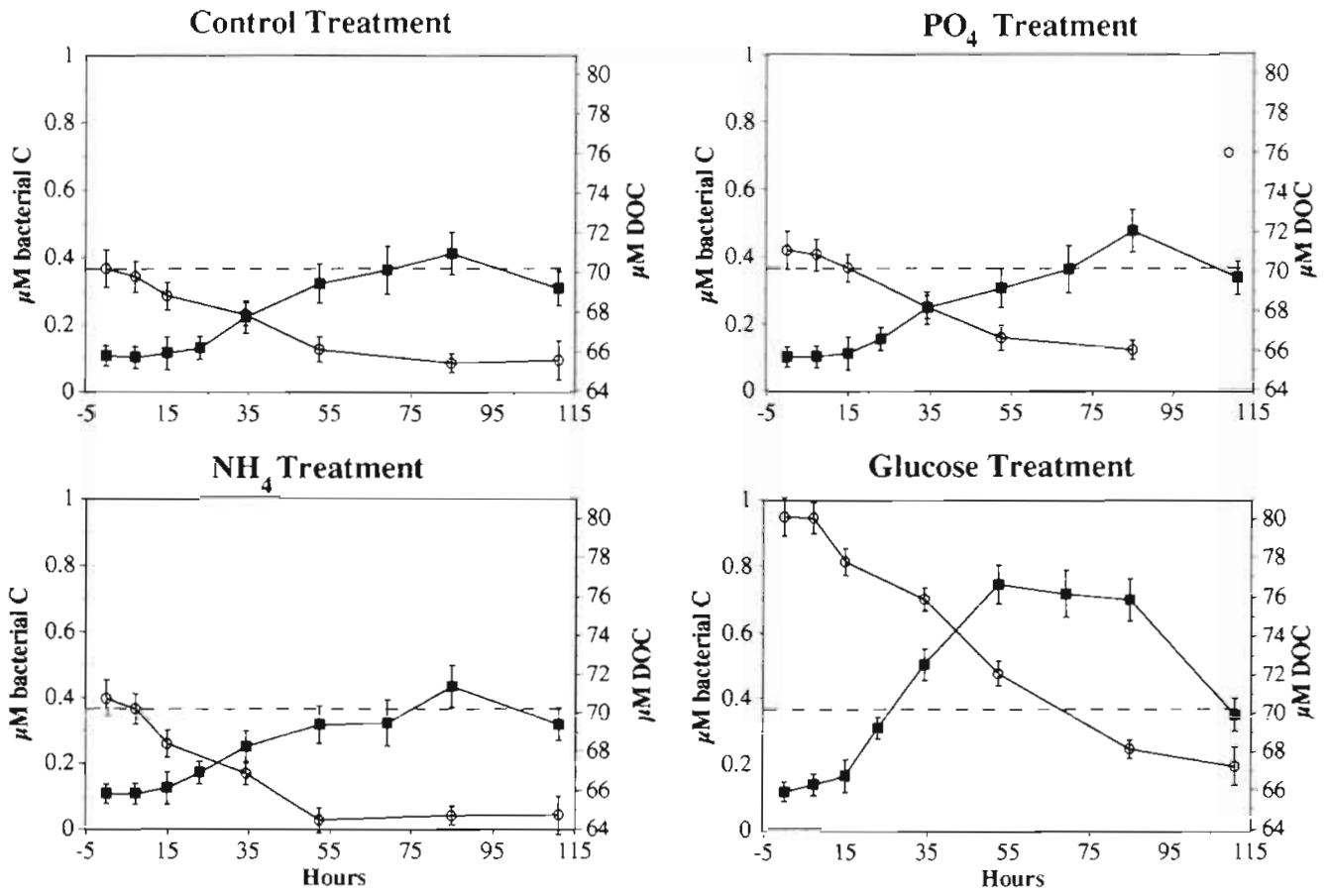

Fig. 8. January 1994 experiment. DOC concentration $(0)$ and bacterial carbon (-) for various seawater cultures treatments including a control, $\mathrm{NH}_{4}, \mathrm{PO}_{4}$, and glucose treatments. Dashed line represents the ambient DOC concentration at time of seawater collection. Error bars represent $1 \mathrm{SD}$ from the mean

and bacterial production from bacterivory. As a result, only the material present in the DOM pool upon collection is available for bacterial utilization. The quality of the biologically reactive component and the rate at which it accumulates depends on the in situ coupling of DOC production and consumption processes (Carlson \& Ducklow 1995). If these processes are tightly coupled, then labile components of the DOC would quickly disappear soon after production processes were halted. Thus, due to the elimination of 'fresh DOC' production, the media collected from a tightly coupled system may not be entirely representative of the material in situ populations were utilizing. If DOC production was greater than consumption, 'fresh' DOC may accumulate, resulting in a longer residence time of available $C$ within the bulk pool.

DOC stacks in the surface $250 \mathrm{~m}$ of the Sargasso Sea demonstrated significant seasonal variability (Carlson et al. 1994); however, the surface mixed layer concentrations did not change seasonally, except for the low concentrations in winter, indicating there was tight coupling between DOC production and consumption processes throughout most of the year. One might expect that if DOC production processes were halted the labile DOC would be removed rapidly leaving behind a more refractory medium for bacterial utilization. Interestingly, we observed growth of natural bacterial assemblages at the expense of ambient DOC only when initial DOC concentrations were greater than concentrations found in the BATS mixed layer. In contrast, cultures that exhibited little or no bacterial growth contained initial DOC concentrations comparable to the BATS mixed layer DOC concentrations (Figs. $2 \& 3$ ). We hypothesize that the 67 to $69 \mu \mathrm{M} \mathrm{C}$ present in the BATS surface mixed layer and in nongrowing cultures represents DOC background concentrations consisting of both semi-labile and refractory components with little or no 'fresh' labile materia] present. When DOC production is halted, the quality of the remaining substrate could not support rapid bacterial growth. Bacterial cultures only grew and utilized DOC during transient episodes of accumulation of labile 'fresh' DOC. Although semi-labile material can be remineralized (Barber 1968, Carlson et al. 1994), turnover times were too long to be measured in our culture experiments, i.e. months.

Actively growing cultures removed 6 to $7 \%$ of the initial DOC by the end of logarithmic growth. This consumed material represented the labile portion of the bulk pool that was available after DOC production was eliminated (Servais et al. 1989). The removal rates of 0.04 to $0.1 \mu \mathrm{M} \mathrm{C} \mathrm{h}^{-1}$ are similar to rates of carbonydrate removal $\left(0.13 \mu \mathrm{M} \mathrm{C} \mathrm{h}{ }^{-1}\right)$ observed by Burney (1986) in the same region. Our rates are higher than those observed by Hansell et al. (1995), who used $\mathrm{CO}_{2}$ accumulation as an index of DOC utilization. However, we suspect that due to the high sensitivity of their analytical procedure the low DOC utilization rates they observed were comparable to those we could not resolve in cultures starting with concentrations similar to the BATS mixed layer values (Figs. 2 \& 3B). By the stationary growth phase, DOC concentrations were 
drawn down to concentrations similar to BATS mixed layer concentrations and did not change significantly throughout the remainder of the experiments (110 to $219 \mathrm{~h}$ ). We hypothesize that the quality of the DOC at the asymptote portion of the DOC utilization curve was representative of the semi-labile and refractory organic compounds.

The experimental approach used in this study yielded an average BGE of $14 \pm 6 \%$ for fast-growing cultures (Table 2), a value considerably lower than the 34 to $95 \%$ observed in studies which traced the disappearance of model compounds through bacterial production (Williams 1970, Iturriaga \& Zsolnay 1981, Goldman et al. 1987, Kirchman 1990). The growth efficiencies we observed in growing cultures varied from 7 to $19 \%$, indicating that the quality of the utilizable DOM or the physiological status of the bacterial assemblage, or both, varied from experiment to experiment. Several studies in which naturally occurring DOM was used to support bacterial growth have demonstrated large temporal and spatial variability of BGE (Table 4). The average BGE of $14 \pm 6 \%$ determined from this study was generally lower than estimates from coastal or inshore waters (Table 4), indicating that accumulated DOM in oligotrophic water was of lower quality than that in eutrophic environments. These values were similar to those of Hansell et al. (1995), who used respiration measurements to assess DOC utilization in the Sargasso Sea. Our data support the findings of Biddanda et al. (1994), who suggested BGE decreased with increasing distance from shore due to decreasing DOM quality. Our data also lend support to the hypothesis of Ducklow \& Carlson (1992) which stated that oligotrophic bacterioplankton must process a greater percentage of primary production to sustain bacterial to primary production ratios similar to those found in eutrophic environments. The high variability and relatively low $\mathrm{BGE}$ emphasize that the use of a constant bacterial conversion efficiency of $50 \%$, often cited in carbon budgets, is inappropriate.

While our estimates of BGE fall within the range reported in the literature, such data must be used cautiously. In order to calculate BGE, accurate estimates of biomass production and DOC consumption are required. Bacterial production estimates in this study were determined by direct observations of changes in bacterial abundance and cell volume. Particulate organic carbon (POC) measurements were not made, due to the large sample volume needed to detect a signal. Thus, to quantify carbon production a CCF was applied to the biovolume measurements. A conservative $\mathrm{CCF}$ of $120 \mathrm{fg} \mathrm{C} \mathrm{mm}^{-3}$ was chosen because Gundersen et al. (1994) found this to be a mid-range CCF for Sargasso Sea bacterioplankton

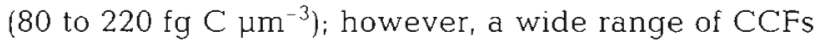
exist in the literature (see Ducklow \& Carlson 1992). The BGE is directly related to the choice of CCF; for

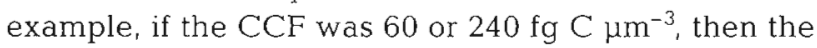
resulting BGE would be 7 or $28 \%$, respectively. A higher $\mathrm{CCF}$ would result in a higher $\mathrm{BGE}$; however,

Table 4. Bacterial growth efficiency values (\%) selected from the literature, determined for natural assemblages of marine bacterioplankton grown on unamended seawater medium. ${ }^{3} \mathrm{H}$-leu: ${ }^{3} \mathrm{H}$-leucine; ${ }^{3} \mathrm{H}$-TdR: ${ }^{3} \mathrm{H}$-thymidine; DIC; dissolved inorganic carbon. $\Delta \mathrm{CO}_{2}$ was measured by high precision coulometric titration. $\triangle \mathrm{DOC}$ was measured using the $\mathrm{HTC}_{\mathrm{C}}$ method. $\Delta \mathrm{O}_{2}$ was measured by high precision titration. Bacterial POC was estimated from cell abundance and cell volumes

\begin{tabular}{|c|c|c|c|c|}
\hline Location & Method & Mean & Range & Source \\
\hline Gulf of Mexico; shelf & $\Delta \mathrm{O}_{2}$ and ${ }^{3} \mathrm{H}-\mathrm{leu}$ & 45 & $38-55$ & Biddanda et al. (1994) \\
\hline Gulf of Mexico; slope & $\Delta \mathrm{O}_{2}$ and ${ }^{3} \mathrm{H}$-leu & 23 & $19-26$ & Biddanda et al. (1994) \\
\hline Roskilde Fjord, Denmark & $\triangle \mathrm{DOC}$ and $\triangle \mathrm{POC}$ & 20 & $11-27$ & Bjørnsen (1986) \\
\hline Southern Ocean & $\triangle \mathrm{DIC}$ and ${ }^{3} \mathrm{H}-\mathrm{TdR}$ & 39 & $38-40$ & Bjørnsen \& Kuparinen (1991) \\
\hline Mississippi River plume & $\Delta \mathrm{O}_{2}$ and ${ }^{3} \mathrm{H}-\mathrm{TdR}$ & 19 & $10-22$ & Chin-Leo \& Benner (1992) \\
\hline Mississippi River plume & $\Delta \mathrm{O}_{2}$ and ${ }^{3} \mathrm{H}$-leu & 29 & $9-42$ & Chin-Leo \& Benner (1992) \\
\hline Northwestern Florida estuaries & $\Delta \mathrm{O}_{2}$ and $\triangle$ Bacterial POC & 43 & $28-58$ & Coffin et al. (1993) \\
\hline Range Salt Marsh, Florida, USA & $\Delta \mathrm{O}_{2}$ and $\Delta$ Bacterial POC & 41 & $11-60$ & Coffin et al. (1993) \\
\hline Santa Rosa Sound, Florida, USA & $\triangle \mathrm{O}_{2}$ and $\triangle$ Bacterial POC & 16 & $0.4-35$ & Coffin et al. (1993) \\
\hline Georgia, USA; inshore & $\Delta \mathrm{O}_{2}$ and ${ }^{3} \mathrm{H}-\mathrm{TdR}$ & 11 & 11 & Griffith et al. (1990) \\
\hline Georgia, USA; nearshore & $\Delta \mathrm{O}_{2}$ and ${ }^{3} \mathrm{H}-\mathrm{TdR}$ & 6 & 6 & Griffith et al. (1990) \\
\hline Georgia, USA; shelf & $\Delta \mathrm{O}_{2}$ and ${ }^{3} \mathrm{H}-\mathrm{TdR}$ & 2 & 2 & Griffith et al. (1990) \\
\hline Sargasso Sea & $\Delta \mathrm{CO}_{2}$ and ${ }^{3} \mathrm{H}-\mathrm{TdR}$ & 6.6 & $3.8-8.9$ & Hansell et al. (1995) \\
\hline Roskilde Fjord, Denmark & $\Delta \mathrm{O}_{2}$ and ${ }^{3} \mathrm{H}-\mathrm{TdR}$ & 42 & 42 & Jensen et al. (1990) \\
\hline North Atlantic $\left(47^{\circ} \mathrm{N}, 18^{\circ} \mathrm{W}\right)$ & $\triangle \mathrm{DOC}$ and $\triangle \mathrm{Bacterial} \mathrm{POC}$ & 5 & $2-8$ & Kirchman et al. (1991) \\
\hline Inshore waters, Florida, USA & $\triangle \mathrm{DOC}$ and $\triangle \mathrm{POC}$ & 47 & $32-61$ & Kroer (1993) \\
\hline Santa Rosa Sound, Florida, USA & $\triangle D O C$ and $\triangle P O C$ & 30 & $26-33$ & Kroer (1993) \\
\hline Gulf of Mexico & $\triangle D O C$ and $\triangle P O C$ & 61 & 61 & Kroer (1993) \\
\hline Baltic Sea & $\triangle \mathrm{DOC}$ and $\triangle \mathrm{Bacterial} \mathrm{POC}$ & 27 & $11-54$ & Zweifel et al. (1993) \\
\hline Northwestern Sargasso Sea & $\triangle \mathrm{DOC}$ and $\triangle \mathrm{Bacterial} \mathrm{POC}$ & 14 & $7-19$ & This study \\
\hline
\end{tabular}




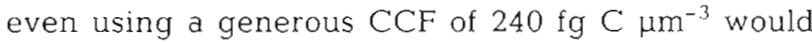
still produce low BGE relative to the often cited $B G E$ of $50 \%$.

DOC utilization was determined by direct measurements of DOC change over time. In cultures in which bacterioplankton did not grow DOC removal could not be resolved, indicating that the DOC changes observed in growing cultures were not due to a abiotic factor such as absorption to particles or to the bottle's wall. However, direct measurement of DOC change could lead to an underestimation of DOC utilization and BGE if DOM was excreted by bacterioplankton (Iturriaga \& Zsolnay 1981) or if viral lysis caused production of DOC (Fuhrman 1992). Thus BGE must be considered a net BGE. In contrast, if viral lysis played a significant role in the loss of bacterial biomass after DOC consumption, then BGE would be underestimated. As discussed in Zweifel et al. (1993), decreases in substrate DOC concentrations may be a misleading measure of growth efficiency unless respiration, DOC decrease, $\mathrm{POC}$, and bacterial numbers and volume are all determined. Thus the BGE determined in this study must be considered first approximations which require further study.

\section{Is organic carbon a limiting nutrient?}

In aquatic environments the assimilation of DOM is dominated by heterotrophic bacterioplankton (Azam \& Hodson 1977); however, bacterioplankton are also capable of utilizing inorganic nitrogen (Wheeler \& Kirchman 1986, Kirchman et al. 1989) and phosphorus (Suttle et al. 1990. Ammerman 1991). Due to the surplus of organic C in surface water of the Sargasso Sea (see Carlson et al. 1994) compared to undetectable concentrations of inorganic nitrogen and phosphate, one might suggest that carbon should not limit bacterial growth. However, it must be stressed that the availability of organic carbon to bacterioplankton is not determined by the absolute concentration of DOC but rather by the quality of the pool (Schaechter et al. 1958, Pomeroy \& Wiebe 1988, Coffin et al. 1993, Biddanda et al. 1994 ). For example, deep-water DOC concentration vaiues represent approximately bs to $70 \%$ of the DOC present in the mixed layer in the Northwestern Sargasso Sea (Carlson et al. 1994), yet this material is approximately 4100 yr old (Bauer et al. 1992) and comprised of biologically refractory material (Barber 1968). Based on vertical and temporal distributions of bulk DOC in oceanic environments, Carlson \& Ducklow (1995) separated the bulk DOC pool into 3 broadly characterized pools, defined as the refractory pool, which turns over on time scales of ocean mixing, the semi-labile pool, which turns over on scales of months to years, and the labile pool, which turns over on scales of hours to days.

Ambient concentrations of individual DFAA in the waters surrounding Bermuda range from $<1$ to $30 \mathrm{nM}$ (Liebezeit et al 1980) and may not be sufficient to sustain bacterial $\mathrm{N}$ demand (Hagström et al. 1984). However, bacterial uptake of $\mathrm{NH}_{4}{ }^{+}$has been shown to supplement this demand (Wheeler \& Kirchman 1986, Kirchman et al. 1989). Except during brief periods of deep winter mixing, the concentrations of inorganic nitrogen and phosphorus in the waters surrounding Bermuda were generally below detection limits (Knap et al. 1994, Michaels et al. 1994). Indeed, Brezinski (1988) reported that concentrations of $\mathrm{NH}_{4}^{+}<3.5 \mathrm{nM}$ were not uncommon in the oligotrophic Sargasso Sea. Under such conditions, bacterial growth could be considered to be limited by both nitrogen (Kroer 1993) and phosphorus (Toolan et al. 1991. Cotner et al. 1994, Peele et al. 1994). Yet, when bacterial cultures were enhanced with inorganic $\mathrm{NH}_{4}{ }^{+}$and $\mathrm{HPO}_{4}{ }^{2}$, there were no significant differences in bacterial growth rates, biomass production, or DOC consumption (Table 3) compared to control treatments. These results indicate that, despite low ambient concentrations, these nutrients were not the primary limiting nutrients to bacteria at the times these culture experiments were conducted.

The results of this study clearly demonstrate in the 3 separate experiments that, despite unmeasurable concentrations of $\mathrm{NH}_{4}{ }^{+}$and $\mathrm{HPO}_{4}{ }^{=}$in surface waters, the addition of labile DOM stimulated bacterial growth rates (Table 3) and biomass yield (Figs. 4 \& 5) during our sampling periods. Organic enrichment yielded significantly higher BGE than the control in 4 of the 6 organic treatments. These results suggest organic carbon limitation and are consistent with the findings of Kirchman et al. (1990), who demonstrated carbon limitation of $\mathrm{NH}_{4}$ uptake and Kirchman (1990), who showed that bacterial production was limited by the supply of amino acids in the subarctic Pacific.

Kirchman $(1990,1994)$ reported that in the subarctic Pacific and the North Atlantic (surface temperature $-12^{\circ} \mathrm{C}$ ), DFAA enrichment stimulated bacterial production more than glucose addition and stated that 'It would be an oversimplification to conclude that heterotrophic bacteria were C-limited'. In contrast to these findings, Goldman \& Dennet (1991) reported no difference in bacterial growth rate or $B G E$ when glucose plus $\mathrm{NH}_{4}$ was compared to DFAA additions in cultures grown on artificial medium. Hobbie \& Crawford (1969) found that a lower percentage of total C uptake was respired with glucose additions than most AA in freshwater bacterial samples. In experiments conducted in the Kiel Fjord, Berman et al. (1994) demonstrated that glucose enrichment stimulated bacterio- 
plankton more than several other organic compounds including alanine. In the present study, there were only slight differences between DFAA and glucose addition with respect to bacterial growth rate, bacterial C production, DOC utilization and BGE. Due to the low $C: N$ ratio of DFAA and an energetic advantage of avoiding AA synthesis, one might expect this treatment to yield higher growth rates and BGEs than nitrogen-poor enrichments (Goldman et al. 1987). Surprisingly, we did not observe this.

One possible explanation is that the added concentrations of DFAA $(\sim 7.5 \mu \mathrm{M})$ were too high compared to the natural $\mathrm{nM}$ concentrations and the oligotrophic bacteria could not utilize the rich substrates sufficiently (i.e. 'oligotrophs' sensu Poindexter 1981). However, studies have demonstrated that most oligotrophic bacteria enriched with concentrations of AA and algal extract significantly higher than in this study grew effectively under high-nutrient conditions (Martin \& MacLeod 1984, Carlucci et al. 1986). In the present study, bacterial growth increased significantly with all organic enrichments compared to the control, indicating that the natural assemblages were able to adjust to elevated nutrient concentrations. A second possibility is that the nutritional value gained from pre-formed AA may have been offset by the energetic costs of transporting AA across the cell membrane (Payne \& Wiebe 1978, Goldman \& Dennet 1991). A third potential explanation as to why bacterioplankton responded similarly to DFAA and glucose treatments may be that after the initial carbon limitation was alleviated, bacterial production became limited by a secondary nutrient. This hypothesis was supported by the results of the July 1993 experiment in which the phytoplankton lysate $(C: N \approx 19)$ produced a higher $B G E$ and yield of bacterial $C$ than glucose and DFAA enrichments. These results indicate that the complex molecular composition of the algal lysate provided a limiting nutrient not supplemented by glucose or DFAA additions, perhaps in the form of dissolved organic phosphorus (DOP), or an organic or inorganic micronutrient.

The algal lysate treatment produced the largest cell yield compared to any other treatment in this study, indicating that cell division was not limited (Fig. 5). DFAA and glucose treatments produced significantly more bacterial $C$ than inorganic and control treatments; however, this elevated carbon production was attributed to a significant increase in cell volume rather than greater cell division. We hypothesize that when cell division became limited, the cells responded to the surplus labile carbon by synthesizing cell products and storing carbon, thus increasing biomass and cell volume. This hypothesis is supported by the findings of Baxter \& Sieburth (1984), who described bacterial strains which could adjust their metabolic strategies to high glucose concentrations by forming cellular storage products. In seawater culture experiments with glucose enrichments, Zweifel et al. (1993) observed that in $\mathrm{N}$ - and P-limited cultures cell division stopped but POC increased. They suggested this POC increase may have resulted from the synthesis of capsular material.

Our study demonstrated that even after cell biomass production became limited and reached the stationary phase, DOC removal continued in the glucose and DFAA treatments. Baxter \& Sieburth (1984) suggested that the production of storage products or extracellular polymeric carbohydrates may result in high glucose uptake rates with low growth efficiencies. We suggest that in an attempt to sequester limiting nutrients, bacterioplankton participated in 'luxurious uptake' of labile carbon which was eventually respired. Our findings indicate that labile carbon in the form of glucose and DFAA was initially utilized as a carbon source, resulting in an elevated growth rate, and that upon exhaustion of a growth-limiting nutrient, the surplus of labile carbon was utilized as an energy source. While labile carbon may be the initial limiting nutrient, it is the availability of all limiting nutrients which dictates the growth efficiency of natural assemblages.

Acknowledgements. We thank the officers and crews of the RV 'Weatherbird II', RV 'Eclipse' and RV 'Cape Hatteras' for their valuable assistance and support. We are grateful to John Dacey, Larry Madin, Tony Michaels, Dave Siegel and Oliver Zafiriou for providing shiptime. We also thank Helen Quinby for assistance in a portion of the microscopy. We thank Tony Knap, Tony Michaels, Dennis Hansell and the staff of the Bermuda Biological Station for Research and BATS for assistance with logistics and laboratory facilities. This work and manuscript benefited greatly from ongoing discussions with Alison Bryant, David Kirchman and Fuh-Kwo Shiah. This research was supported by the National Science Foundation grant OCE 90-15888 to H.W.D. and C.A.C. This is CEES contribution no. 2702. This is BBSR contribution no. 1418 .

\section{LITERATURE CITED}

Ammerman JW (1991) Role of ecto-phosphohydrolases in phosphorus regeneration in estuarine and coastal ecosystems. In: Chrost RJ (ed) Microbial enzymes in aquatic environments. Springer-Verlag, New York, p 165-186

Ammerman JW, Fuhrman JA, Hagström $\AA$, Azam F (1984) Bacterioplankton growth in seawater: I. Growth kinetics and cellular characteristics in seawater cultures. Mar Ecol Prog Ser 18:31-39

Azam F, Hodson RE (1977) Size distribution and activity of marine microheterotrophs. Limnol Oceanogr 22:492-501

Baldwin WW, Bankston PW (1988) Measurement of live bacteria by Nomarski interference microscopy and steriologic methods as tested with macroscopic rod-shaped models. Appl environ Microbiol 54:105-109

Barber RT (1968) Dissolved organic carbon from deep water resists microbial oxidation. Nature 220:274-275 
Bauer JE, Williams PM, Druffel ERM (1992) ${ }^{14} \mathrm{C}$ activity of dissolved organic carbon fractions in the north-central Pacific and Sargasso Sea. Nature $3.57 \cdot 667-670$

Baxter M, Sieburth JM (1984) Metabolic and ultrastructural response to glucose of two eurytrophic bacteria isolated from seawater at different enriching concentrations. Appl environ Microbiol 47:31-38

Benner R, Strom M (1993) A critical evaluation of the analytical blank associated with DOC measurements by hightemperature catalytic oxidation. Mar Chem 41:153-160

Berman T, Hoppe HG, Gocke K (1994) Response of aquatic bacterial populations to substrate enrichments. Mar Ecol Prog Ser 104:173-184

Biddanda B, Opsahl S, Benner R (1994) Plankton respiration and carbon flux through bacterioplankton on the Louisiana shelf. Limnol Oceanogr 39:1259-1275

Bjørnsen PK (1986) Bacterioplankton growth yield in continuous seawater cultures. Mar Ecol Prog Ser 30:191-196

Bjornsen PK, Kuparinen J (1991) Determination of bacterioplankton biomass, net production and growth efficiency in the Southern Ocean. Mar Ecol Prog Ser 71:185-194

Biezinski $M$ (1988) Vertical distribution of ammonium in stratified oligotrophic waters. Limnol Oceanogr 33:1176-1182

Burney CM (1986) Bacterial utilization of total in situ dissolved carbohydrate in offshore waters. Limnol Oceanogr 31:427-431

Carlson CA, Ducklow HW (1995) Dissolved organic carbon in the upper ocean of the central Equatorial Pacific, 1992: daily and fine scale vertical variations. Deep Sea Res 42 : $639-656$

Carlson CA, Ducklow HW, Michaels AF (1994) Annual flux of dissolved organic carbon from the euphotic zone in the Northwestern Sargasso Sea. Nature 371:405-408

Carlson CA, Ducklow HW, Sleeter TD (1995) Stocks and dynamics of bacterioplankton in the Northwestern Sargasso Sea. Deep Sea Res (in press)

Carlucci AF, Shimp SL, Craven DB (1986) Growth characteristics of low-nutrient bacteria from the north-east and central Pacific Ocean. FEMS Microbiol Ecol 38:1-10

Chin-Leo G, Benner R (1992) Enhanced bacterioplankton production and respiration at intermediate salinities in the Mississippi River plume. Mar Ecol Prog Ser 87:87-103

Chin-Leo G, Kirchman DL (1990) Unbalanced growth in natural assemblages of marine bacterioplankton. Mar Ecol Prog Ser 63:1-8

Coffin RB, Connolly JP, Harris PS (1993) Availability of dissolved organic carbon to bacterioplankton examined by oxygen utilization. Mar Ecol Prog Ser 101:9-22

Cole JJ, Findlay S, Pace ML (1988) Bacterial production in fresh and saltwater ecosystems: a cross-system overview. Mar Ecol Prog Ser 43:1-10

Copin-Montégut $G$, Avril B (1993) Vertical distribution and temporal variation of dissolved organic carbon in the North-Western Mediterranean Sea. Deep Sea Res 40: $1963-1972$

Cotner JB, Peele ER, Ammerman JW, Bentzen E (1994) Phosphorus-limited plankton growth in the Sargasso Sea (BATS) and implications of the pelagic food web. EOS 75:75

Ducklow HW, Carlson CA (1992) Oceanic bacterial production. Adv mar Biol 12:113-181

Ducklow HW, Kirchman DL, Quinby HL (1992) Bacterioplankton cell growth and macromolecular synthesis in seawater cultures during the North Atlantic Bloom spring phytoplankton bloom. May 1989. Microb Ecol 24:125-144

Ducklow HW, Kirchman DL, Quinby HL, Carlson CA, Dam HG (1993) Stocks and dynamics of bacterioplankton dur-
Ing the spring bloom in the eastern North Atlantic Ocean. Deep Sea Res II 40:245-263

Fuhrman JA (1992) Bacterioplankton roles in cycling of organic matter: the microbial food web. In: Falkowskı PG. Woodhead AW (eds) Primary productivity and biogeochemical cycles in the sea. Plenum Press, New York, $p$ 361-383

Fuhrman JA, Ammerman JW, Azam F (1980) Bacterioplankton in the coastal euphotic zone: distribution, activity and possible relationships with phytoplankton. Mar Biol 60: $201-207$

Fuhrman JA, Azam F (1982) Thymidine incorporation as a measure of heterotrophic bacterioplankton production in marine surface waters: evaluation and field results. Mar Biol 66:109-120

Fuhrman JA, Bell TM (1985) Biological considerations in the measurement of dissolved free amino acids in seawater and implications for chemical and microbiological studies Mar Ecol Prog Ser 25:13-21

Fuhrman JA, Sleeter TD, Carlson CA, Proctor LM (1989) Dominance of bacterial biomass in the Sargasso Sea and its ecological implications. Mar Licol Prog Ser 57:207-217

Goldman JC. Caron DA, Dennett MR (1987) Regulation of gross growth efficiency and ammonium regeneration in bacteria by substrate $\mathrm{C}: \mathrm{N}$ ratio. Limnol Oceanogr 32 : $1239-1252$

Goldman JC, Dennet MR (1991) Ammonium regeneration and carbon utilization by marine bacteria grown on mixed substrates. Mar Biol 109:369-378

Goldman JC, Hansell DA, Dennett MR (1992) Chemical characterization of three large oceanic diatoms: potential impact on water column chemistry. Mar Ecol Prog Ser 88: $257-270$

Griffith PC, Douglas DJ, Wainright SC (1990) Metabolic activity of size-fractionated microbial plankton in estuarine, nearshore, and continental shelf waters of Georgia. Mar Ecol Prog Ser 59:263-270

Gundersen K. Heldal M. Norland S (1994) Single cell bacterial carbon and nitrogen in the Sargasso Sea. EOS 75:100

Hagström $\AA$, Ammerman JW, Henrichs S, Azam F (1984) Bacterioplankton growth in seawater: II. Organic matter utilization during steady-state growth in seawater cultures. Mar Ecol Prog Ser 18:41-48

Hansell DA, Bates NR, Gundersen K (1995) Mineralization of dissolved organic carbon in the Sargasso Sea. Mar Chem (in press)

Hobbie JE, Crawford CC (1969) Respiration correction for bacterial uptake of dissolved organic compounds in natural waters. Limnol Oceanogr 14:528-533

Hobbie JE, Daley JR, Jasper S (1977) Use of Nuclepore filters for counting bacteria by epifluorescence microscopy. Appl Environ Microbiol 33:1225-1228

Hopkinson CS, Sherr B, Wiebe WJ (1989) Size fractionated metabolism of coastal microbial plankton. Mar Ecol Prog Ser 51:155-166

Hulbert SH (1984) Pseudoreplication and the design of ecological field experiments. Ecol Monogr 54:187-211

Iturriaga R. Zsolnay A (1981) Transformation of some dissolved organic compounds by natural heterotrophic populations. Mar Biol 62:125-129

Jensen LM, Sand-Jensen K, Marcher S, Hansen M (1990) Plankton community respiration along a nutrient gradient in a shallow Danish estuary. Mar Ecol Prog Ser 61:75-85

Keil RG, Kirchman DL (1991) Contribution of dissolved free amino acids and ammonium to the nitrogen requirements of heterotrophic bacterioplankton. Mar Ecol Prog Ser 73 : $1-10$ 
Kirchman DL (1990) Limitation of bacterial growth by dissolved organic matter in the subarctic Pacific. Mar Ecol Prog Ser 62:47-54

Kirchman DL (1994) The uptake of inorganic nutrients by heterotrophic bacteria. Microb Ecol 28:255-271

Kirchman DL, Keil RG, Wheeler PA (1989) The effect of ammo acids on ammonium utilization and regeneration by heterotrophic bacteria in the subarctic Pacific. Deep Sea Res $36: 1763-1776$

Kirchman DL, Keil RG, Wheeler PA (1990) Carbon limitation of ammonium uptake by heterotrophic bacteria in the subarctic Pacific. Limnol Oceanogr 35:1267-1278

Kirchman DL, K'nees E, Hodson RE (1985) Leucine incorporation and its potential as a measure of protein synthesis by bacteria in natural aquatic systems. Appl environ Microbiol 49:599-607

Kirchman DL, Suzuki Y, Garside C, Ducklow HW (1991) High turnover rates of dissolved organic carbon during a spring phytoplankton bloom. Nature 352:612-614

Knap AH, Michaels AF, Dow RL, Johnson RJ, Gundersen K, Sorensen JC, Close AR, Howse FA, Bates N, Best M, Hammer M, Doyle AP (1994) BATS data report. Bermuda Biological Station for Research Inc, Woods Hole Oceanographic Institution, Woods Hole, MA

Kroer N (1993) Bacterial growth efficiency on natural dissolved organic matter. Limnol Oceanogr 38:1282-1290

Lampert W (1978) Release of dissolved organic carbon by grazing zooplankton. Limnol Oceanogr 23:831-834

Lancelot C (1979) Gross excretion rates of natural marine phytoplankton and heterotrophic uptake of excreted products in the southern North Sea, as determined by short-term kinetics. Mar Ecol Prog Ser 1:179-186

Liebezeit G, Bölter M, Brown F, Dawson R (1980) Dissolved free amino acids and carbohydrates at pycnocline boundaries in the Sargasso Sea and related microbial activity. Oceanol Acta 3:357-362

Martin P, MacLeod RA (1984) Observations on the distinction between oligotrophic and eutrophic marine bacteria. Appl environ Microbiol 47:1017-1022

Menzel DW, Ryther JH (1960) The annual cycle of primary production in the Sargasso Sea off Bermuda. Deep Sea Res 6:351-367

Michaels AF, Knap AH, Dow RL, Gundersen K, Johnson RJ, Sorensen J, Close A, Knauer GA, Lohrenz SE, Asper VA, Tuel M, Bidigare R (1994) Seasonal patterns of ocean biogeochemistry at the U.S. JGOFS Bermuda Atlantic Timeseries Study site. Deep Sea Res 41:1013-1038

Nagata T, Kirchman DL (1992) Release of dissolved organic matter by heterotrophic protozoa: implications for microbial foodwebs. Arch Hydrobiol 35:99-109

Payne WJ, Wiebe WJ (1978) Growth yield and efficiency in chemosynthetic microorganisms. A Rev Microbiol 32: $155-183$

Peele ER, Ammerman JW, Bentzen E, Cotner JB (1994) Microbial hydrolysis of dissolved organic phosphorus compounds at the Bermuda Time-series station. EOS 75 : 76

Peltzer ET, Brewer PG (1993) Some practical aspects of measuring DOC-sampling artifacts and analytical problems with marine samples. Mar Chem 41:243-252

Responsible Subject Editor: F. Azam, La Jolla, California, USA
Peltzer ET, Hayward NA (in press) Spatial distribution and temporal variability of total organic carbon along $140^{\circ} \mathrm{W}$ in the equatorial Pacific Ocean in 1992. Deep Sea Res Il

Poindexter JS (1981) Oligotrophy fast and famine existence. In: Alexander $M$ (ed) Advances in microbial ecology. Plenum Press, New York, p 63-90

Pomeroy LR (1974) The ocean's food web, a changing paradigm. BioSci 24:499-504

Pomeroy LR, Wiebe WJ (1988) Energetıcs of microblal food webs. Hydrobiologia 159:7-18

Proctor LM, Fuhrman JA (1990) Viral mortality of marine bacterla and cyanobacteria. Nature 343:60-62

Schaechter M, Maaloe O, Kjeldgaard NO (1958) Dependency on medium and temperature of cell size and chemical composition during balanced growth of Salmonella typhimurium. J gen Microbiol 19:592-606

Servais P, Anzil A, Ventresque C (1989) Simple method for determination of biodegradable dissolved organic carbon in water. Appl environ Microbiol 55:2732-2734

Sharp JH, Benner R, Bennett L, Carlson CA, Dow RL, Fitzwater SE (1993) Re-evaluation of high temperature combustion and chemical oxidation measurement of dissolved organic carbon in seawater. Limnol Oceanogr 38: $1774-1782$

Sharp JH, Benner R, Bennett L, Carlson CA, Fitzwater SE, Peltzer ET, Tupas LM (1994) Analyses of dissolved organic carbon in seawater the JGOFS EqPac methods comparison. Mar Chem 48:91-108

Shiah FK, Ducklow HW (1994) Temperature and substrate regulation of bacterial abundance, production and specific growth rat in Chesapeake Bay, USA. Mar Ecol Prog Ser 103:297-308

Smith D, Simon M, Alldredge AL, Azam F (1992) Intense hydrolytic enzyme activity on marine aggregates and implications for rapid particle dissolution. Nature 359:139-142

Suttle CA, Fuhrman JA, Capone DG (1990) Rapid ammonium cycling and concentration-dependent partitioning of ammonium and phosphate: implications for carbon transfer in planktonic communities. Limnol Oceanogr 35:424-433

Toolan T, Wehr JD, Findlay S (1991) Inorganic phosphorus stimulation of bacterioplankton production in a mesoeutrophic lake. Appl environ Microbiol 57:2074-2078

Watson SW, Novitsky TJ, Quinby HL, Valois FW (1977) Determination of bacterial number and biomass in the marine environment. Appl environ Microbiol 33:940-946

Wheeler PA, Kirchman DL (1986) Utilization of inorganic and organic nitrogen by bacteria in marine systems. Limnol Oceanogr 31:998-1009

Williams PJLB (1970) Heterotrophic utilization of dissolved organic compound in the sea. I. Size distribution of population and relationship between respiration and incorporation of growth substrates. J mar biol Ass UK 50:859-870

Williams PJLB (1981) Incorporation of microheterotrophic processes into the classical paradigm of the planktonic food web. Kieler Meeresforsch 5:1-28

Williams PM, Druffel ER (1988) Dissolved organic matter in the ocean: comments on a controversy. Oceanography 1:14-17

Zweifel UL, Norrman B, Hagström $\AA$ (1993) Consumption of dissolved organic carbon by marine bacteria and demand for inorganic nutrients. Mar Ecol Prog Ser 101:23-32

Manuscript first received: July 3, 1995

Revised version accepted: November 2, 1995 